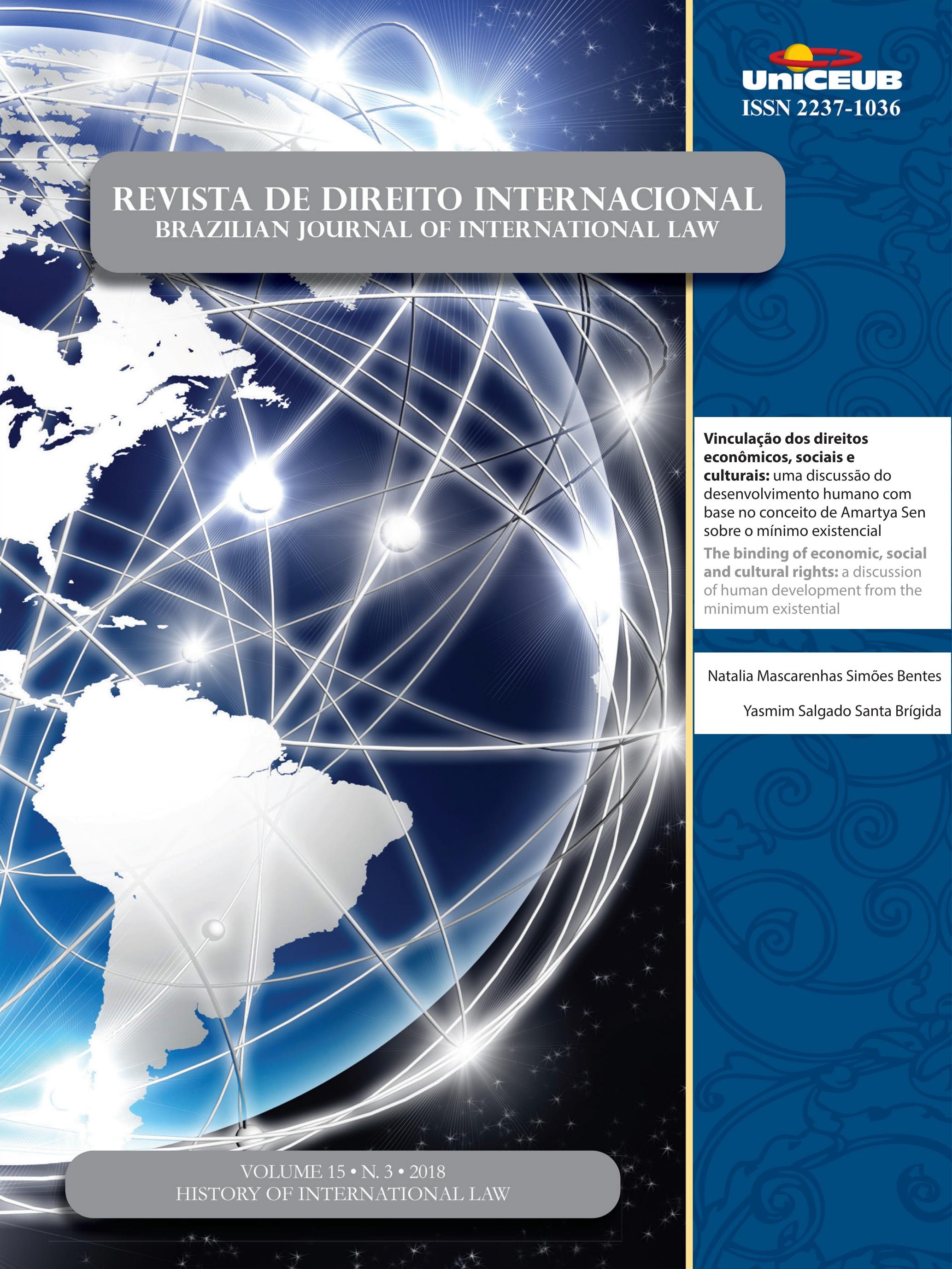




\section{Sumário}

I. Dossiê Especial: History of International Law ...................................1

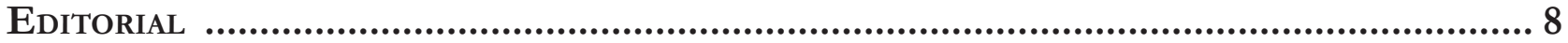

What does it mean to apply history in international law studies? ....................................................... 8

Arthur Roberto Capella Giannattasio

SuR LA NATURE DU Droit ISLAMIQUe............................................................................14

Hocine Benkheira

Islamic Shari’a Law, History and Modernity: Some Reflections .................................25 Suleiman A. Mourad

The (Un)practical Secularization Process: International Law and Religion as So-

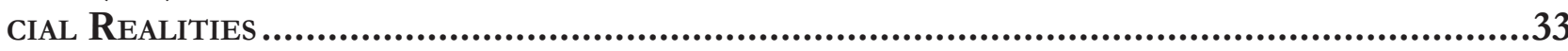

Douglas de Castro

BRAZILIAN LITERATURE ON INTERNATIONAL LAW DURING THE EMPIRE REGIME. OR THE DIFFUSION OF INTERNATIONAL LAW IN THE PERIPHERIES THROUGH APPROPRIATION AND ADAPTATION.

Airton Ribeiro da Silva Júnior

Natural, POSitivo, romano E Universal? INVESTigaÇão SObre O Direito das GENTES EM

Tomás de Aquino

Rafael Zelesco Barretto

II. Artigos sobre outros temas

VINCULAÇÃO DOS DIREITOS ECONÔMICOS, SOCIAIS E CULTURAIS: UMA DISCUSSÃO DO DESENVOLVImento humano com base no conceito de Amartya Sen sobre o mínimo existencial.....99

Natalia Mascarenhas Simões Bentes e Yasmim Salgado Santa Brígida

A NOVA LeI de MigraÇão E A PROTEÇão CONFERIDA AO APÁtrida: ALINHAMENTO BRASILEIRO AO PADRÃO INTERNACIONAL DE DIREITOS HUMANOS

Pedro Henrique de Faria Barbosa e Sylvio Loreto

E se o Supremo Tribunal Federal (STF) restabelecer a vigência da Convenção n. 158 
da Organização Internacional do Trabalho (OIT) na ordem Jurídica brasileira? SoBRE UMA POSSÍVEL REVIRAVOLTA, PELA VIA DO DIREITO INTERNACIONAL, DAS LEIS TRABALHISTAS BRASILEIRAS 138

Daniel Damasio Borges

JULGADOS DA CORTE INTERAMERICANA SOBRE CASOS BRASILEIROS E POLÍTICAS PÚBLICAS: REFLEXÕES ACERCA DE POSSÍVEIS INFLUIÇÕES 165

Rafael Osvaldo Machado Moura

CREATING BRIDGES BETWEEN INTERNATIONAL RELATIONS THEORY AND INTERNATIONAL HUMAN RIGHTS LAW: CONSTRUCTIVISM AND THE ROLE OF BRAZIL IN THE INTER-AMERICAN SYSTEM OF HUMAN RIGHTS 179

Ismael Francisco de Souza, Luciana Rocha Leme e Erick da Luz Scherf

Justiça de transição na Argentina e o Sistema Interamericano de Direitos Humanos: uMa ANÁlise do CASo Luis Muiña (“REgRa 2x1”) 199

Emilio Peluso Neder Meyer e Jessica Holl

A legalidade e legitimidade da INTERVEnÇão humanitÁria: UMA MEDIDA AINDA NECESSÁRIa.219 Natália Caye Batalha Boeira

O Acordo de Escazú E o ACESSo À INFORMaÇão AMbiental no Brasil. 252 Érica Bezerra Queiroz Ribeiro e Bruno Amaral Machado

Dos POVOS NATIVOS AO SURGIMENTO DOS MOVIMENTOS SOCIAIS: INFLUÊNCIAS DOS DISCURSOS JURÍDICOS, RELIGIOSOS E MÉDICOS PARA A CONSTRUÇÃO DO CONCEITO DE HOMOSSEXUALIDADE NO BRASIL .267 Bruno Rafael Silva Nogueira Barbosa e Robson Antão de Medeiros

Aspectos Jurídicos da PARTicipaÇão dA UNião Europeia NA OMC: COMPREENDENdo SUTILEZAS DE UM DELICADO ENLACE. 291

Camilla Capucio

Path to judicial activism? The use of "Relevant rules of international law" by the WTO Appellate Body

Mariana Clara de Andrade

LEVEZA E PESO NA MEDIAÇÃO COMERCIAL INTERNACIONAL: O CONTEÚDO JURÍDICO DO ACORDO CORPORATIVO MEDIADO E SUA INCORPORAÇÃo PELO DiREITO BRASILEIRO .324 Henrique Lenon Farias Guedes 
JURISDIÇÃO INTERNACIONAL E AS DIFICULDADES DE EXECUÇÃO DE SENTENÇAS INTERNACIONAIS NO BRASIL

Nevitton Vieira Souza

O DEVER DE COOPERAÇÃo NOS CONTRATOS DE VENDA INTERNACIONAL DE MERCADORIAS: PRESSUPOSTOS TEÓRICOS E REPERCUSSÕES PRÁTICAS DA CLÁUSULA GERAL DA BOA-FÉ OBJETIVA PARA A APLICAÇÃo DA CISG .358

Angelo Gamba Prata de Carvalho

A DiMENSÃo JURÍdiCA DO IMPERIALISMO NA (DES)ORDEM GLOBAL CAPITALISTA: UMA ANÁLISE COM BASE NA CRÍTICA MARXISTA AO DIREITO INTERNACIONAL E ÀS RELAÇÕES POLÍTICO-ECONÔMICAS DE DOMINAÇÃO E DEPENDÊNCIA.

Thomaz Delgado De David, Maria Beatriz Oliveira da Silva e Rosane Beatris Mariano da Rocha Barcellos Terra

A participaÇão de Brasil e Estados Unidos na formulação das regras multilaterais do

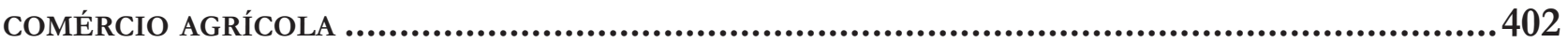

Vera Thorstensen, Vivian Daniele Rocha Gabriel e Alebe Linhares Mesquita

A galáxia lex e a construÇão de um Sistema jurídico transnacional ........................ 441

Eugênia Cristina Nilsen Ribeiro Barza e Jéssyka Maria Nunes Galvão

Has the Ability of Truth Commissions to Recommend Amnesty Been Effective in Enhancing Perpetrator Cooperation? 453 Jeremy Sarkin

A CONCEPTUAL PAPER ON THE POLICY-FRAMEWORK THAT MIRRORS THE DYNAMIC LINK BETWEEN Human Security, Social Protection and Safety Nets, and Food and Nutritional Security: The Case of the "Gulayan sa Paaralan Program", the Philippines.... 478 Renato Lagapa Base

INCENTIVISING SMALLHOLDER FARMER LIVELIHOODS AND CONSTRUCTING FOOD SECURITY THROUGH HOME-GROWN SCHOOL FEEDING: EVIDENCE FROM NORTHERN GHANA .491

Clement Mensah

Policy COHERENCE In THE IMPLEMENTATION OF THE 2030 AgENDA FOR SUSTAINABLE DEVELOpment: the Brazilian School Feeding Programme Case Study .506 Mariana Werlang Girardi 


\title{
Vinculação dos direitos econômicos, sociais e culturais: uma discussão do desenvolvimento humano com base no conceito de Amartya Sen sobre o mínimo existencial*
}

\author{
The binding of economic, social and cultural \\ rights: a discussion of human development \\ from the minimum existential
}

\author{
Natalia Mascarenhas Simões Bentes** \\ Yasmim Salgado Santa Brígida***
}

\section{Resumo}

Apresenta-se o que são os Direitos Econômicos, Sociais e Culturais (DESC), com foco nos tratados internacionais, por meio da vinculação de responsabilidades assumidas pelos Estados partes, fiscalizados por mecanismos de controle internacionais e pelo controle de convencionalidade nacional. Pretende-se relacionar a concepção internacional dos DESC e as liberdades na Teoria das Capacidades de Amartya Sen com a ampliação do mínimo existencial para a fundamentação de medidas judiciais que concedam direitos sociais no Brasil. Objetiva-se entender a necessidade das liberdades substantivas para as realizações de objetivos individuais e coletivos. Identifica-se o papel dos bens humanos básicos ofertados pelos DESC na promoção de capacidades, expor o viés positivo e negativo tanto dos direitos civis e políticos quanto sociais e culturais para o aumento de liberdades gerais. A pesquisa é bibliográfica qualitativa com análise doutrinária dos DESC. Conclui-se que as capacidades decorrem do aumento de liberdades substantivas possíveis por meio dos DESC e da atuação judiciária na concessão de direitos sociais, responsáveis pelos bens humanos básicos que permitirão o aumentando do bem-estar humano e consequentemente, o desenvolvimento econômico e social.

Palavras-chave: DESC. Direitos Humanos. Teoria das Capacidades.

* Recebido em: 03/08/2018 Aprovado em: 07/12/2018

** Doutora em Direito Público pela Faculdade de Direito da Universidade de Coimbra, Portugal. Mestre em Direito pela Faculdade de Direito da Universidade do Porto, Portugal. Bacharel em Direito pela Universidade Federal do Pará. Professora do Centro Universitário do Estado do Pará e da Escola Superior da Magistratura do Estado do Pará. Coordenadora da Clínica de Direitos Humanos do CESUPA. Coordenadora Adjunta do Curso de Direito do Centro Universitário do Estado do Pará. Advogada. E-mail : natysimoes@hotmail.com

*** Discente do Curso de Direito do Centro Universitário do Estado do Pará. E-mail: yasmimsantabrigida@gmail.com

\section{Abstract}

Economic, Social and Cultural Rights (DESC) are presented, with a focus on international treaties, through the binding of responsibilities assumed by the States parties, controlled by international control mechanisms and by the control of national convention. It is intended to relate the international conception of ESCR and liberties in Amartya Sen's theory of capacities with the expansion of the existential minimum in the foundation of judicial measures that grant social rights in Brazil. It is intended to understand the need for substantive freedoms for the achievement of individual and collective goals. It identifies the role of basic human goods offered by ESCR in capacity-building, exposing the positive and negative bias of both civil and 
political and social and cultural rights for the enhancement of general freedoms. The research is a qualitative bibliography with a doctrinal analysis of ESCR. It is concluded that capacities stem from the increase of substantive freedoms through the effectiveness and real guarantees of ESCR through judicial actions in the granting of social rights, responsible for the basic human goods that will allow the realization of personal and collective operations, the chances of human well-being and the quality of life, as a consequence there is the economic and social development.

Keywords: DESC. Human Rights. Theory of Capabilities.

\section{INTRODUÇÃo}

O presente artigo visa relacionar a concepção internacional dos DESC e as liberdades na teoria das capacidades de Amartya Sen com a ampliação do mínimo existencial a respeito da fundamentação de medidas judiciais que concedam direitos sociais no Brasil. Para tanto, o artigo demonstra a vinculação e impacto do direito internacional (decisões, tratados normativos e monitoramento de organismos internacionais) com o direito interno brasileiro, visto que o país é Estado-Parte responsável por cumprir com obrigações perante a comunidade internacional (principalmente pelo controle de convencionalidade), sendo uma delas a política de efetivação dos direitos fundamentais, em especial os DESC.

Para isso, o histórico dos direitos é apresentado pela teoria das gerações no direito internacional com a finalidade de se chegar à ampliação do mínimo existencial.

Segundo a visão de Jorge Reis Novais, analisam-se as críticas quanto à positivação específica, indeterminabilidade de conteúdo, e a ordem estrutural dos DESC que impediriam a eficácia destes, além da impossibilidade do tratamento igualitário entre os direitos (civis e políticos com os econômicos e sociais).

Nesse sentido, aborda-se o aspecto econômico na concretude dos direitos, visto que, por meio dos estudos dos custos: 1) serão escolhidas as políticas de gastos públicos e 2) direcionadas as medidas judiciais. $\mathrm{O}$ autor afirma que a garantia dos direitos sociais permite uma melhor condição de exercício dos direitos de liberdades gerais, por meio da atuação positiva (direta ou indireta) ou negativa do Estado. Daí, discute-se a melhor interpretação do conceito do mínimo existencial para a atuação estatal, com o foco na atuação judicial.

Em seguida, a abordagem da "teoria das capacidades" de Amartya Sen será direcionada para os pontos que interessam à questão dos DESC, quais sejam: 1) a definição de liberdades; 2) a relação entre desenvolvimento econômico e o aumento da qualidade de vida propiciada pela efetivação dos DESC, a partir da expansão de liberdades. Outros pontos da Teoria de Sen serão trazidos para uma breve compreensão das liberdades em relação à “Teoria das Capacidades", no entanto, a atenção estará voltada para os pontos já citados, pois se relacionam ao objeto deste estudo.

Por fim, tem-se a interpretação do mínimo existencial abrangente com os direitos econômicos, sociais e culturais, fundamentada no aumento de liberdades segundo a Teoria das Capacidades para solucionar a proposta do presente trabalho, relativa à ampliação do reconhecimento judicial de pleitos assistenciais.

\section{A PROTEÇÃO INTERNACIONAL dOS DIREITOS ECONÔMICOS, SOCIAIS E CULTURAIS}

O corpus juris da proteção internacional dos Direitos Humanos perpassa a decorrência do respeito ao outro, conforme a universalidade da sacralidade da pessoa humana e o Princípio da Igualdade, ou da "não discriminação".

Devido a poucas tentativas de implementação regional dos Direitos Econômicos Sociais e Culturais $(\mathrm{DESC})^{1}$, por terem sido negligenciados, vem ocorrendo, nos últimos anos, um aumento exponencial em relação a sua legalização, judicialização e legitimação².

Existem fortes críticas a tal "modalidade" de direitos: a ilegitimidade democrática não só dos DESC, como também dos direitos humanos, no sentido da Teoria da Separação dos Poderes. Se os tribunais delegassem ao

1 No rol destes se encontram: o direito à saúde, à previdência social, à moradia, à educação, à participação na vida cultural e ao progresso científico e tecnológico, os quais são essenciais para que se exerça os direitos civis e políticos.

2 LANGFORT, Malcolm. Judicialização dos direitos econômicos, sociais e culturais no âmbito nacional: uma análise sócio jurídica. Revista Internacional de Direitos Humanos, São Paulo, v. 6, n. 11, p. 98133, 2009. 
juiz o papel de realizar tais tarefas, estariam excedendo a função que lhes corresponde, e concedendo-lhe uma função política. As doutrinas tradicionais consideram que os DESC, assim como os direitos civis e políticos, devem ser protegidos na qualidade de direitos fundamentais (papel especificamente jurídico ou deliberativo do Poder Judiciário), como no caso Suíca vs. Kantons, 1995, no qual a Corte Federal da Suíça justificou a derivação do direito a uma subsistência mínima a partir de uma série de direitos civis e políticos. Derivaram, assim, o caráter fundamental dos DESC com base nos direitos civis, e não por serem fundamentais per si.

Outra objeção persistente de tais doutrinas é institucional, pois os juízes não possuem capacidade para essa tarefa, já que carecem de conhecimentos específicos necessários (econômicos e sociais).

No entanto, como garantir o direito de ir e vir sem o direito à moradia? Como fazer o cidadão exercer o seu direito à participação de vida pública sem antes ter o direito básico à alimentação?

Apesar dessas limitações reais, atualmente, como resposta à crítica da incapacidade temática, a justiça faz uso de órgãos especializados, peritos e petições de amicus curiae. Todas as áreas da justiciabilidade implicam questões policêntricas. Uma solução para esse conflito constitui o uso de princípios jurídicos claramente definidos, como a razoabilidade, os remédios judiciais.

O número de decisões que invocam a implementação dos DESC testemunha a tendência à progressão de sua implementação, devido à adoção de procedimentos de denúncias e investigações do PIDESC (Pacto Internacional de Direitos Econômicos, Sociais e Culturais de 1966) ${ }^{3}$, assim como as reformas constitucionais para cada membro se adequar às exigências sociais. Em decorrência disso, há o requisito de admissibilidade de um caso, para responsabilização por uma corte internacional, mediante o instituto do esgotamento dos recursos

3 O PIDESC faz parte do sistema global, que possui mecanismos convencionais e não convencionais de promoção e tutela dos direitos humanos. O primeiro consiste no sistema de comunicações interestatais e de relatórios criados por tratados ao disporem sobre mecanismos de supervisão e controle. $\mathrm{O}$ segundo faz referência à investigação in loco, em casos urgentes e graves, quando há a anuência do estado demandado, com colheita e apreciação de provas. TAQUARY, Eneida Orbage. A proteção à pessoa humana: sistema normativo de proteção global geral. Universitas Jus, Brasília, v. 25, n. 1, p. 143-151, abr. 2014. internos ${ }^{4}$, onde cada país terá a sua própria jurisdição para solucionar seus assuntos, e tentar se adequar regionalmente aos direitos do PIDESC, conforme as suas recomendações.

Um exemplo de decisões que invocam os DESC ocorreu na Índia, primeiro país a consolidar uma jurisprudência madura sobre os DESCs, em 1970, com o entendimento amplo para o conceito de vida, incluindo direitos econômicos e sociais, como o presenciado no caso Municipal Council Ratlam vs. Vardhichand and others, onde a Corte Suprema da Índia determinou que o município deveria fornecer água, saneamento básico e sistema de esgoto para os requerentes ${ }^{5}$.

A genealogia desses direitos remonta ao pós-Segunda Guerra Mundial, onde houve a necessidade da proteção de toda a sociedade, após o trauma da experiência nazista, visto que era essencial a estipulação de valores universais, com a criação de sistemas globais e regionais de proteção aos Direitos Humanos. Assim, por meio da criação da Carta das Nações Unidas, em 1945, vários países aderiram à Organização das Nações Unidas.

Em 1947, o ECOSOC ${ }^{6}$ estabeleceu a Comissão de Direitos Humanos para a preparação da Declaração Universal dos Direitos Humanos (o rol de direitos humanos assegurados), ocorrida em 1948, influenciada pela política norte-americana do presidente Roosevelt, defensor da ideia de que o ser humano necessitado não é livre. Dessa forma, a legislação internacional precisava de instrumentos de vinculação a tais direitos, por meio de mecanismos que fiscalizassem os Estados para colocar em prática políticas de efetivação regional. Nesse sentido, a construção dos Direitos Humanos adotada

4 No art. 46 da CADH: "1. Para que uma petição ou comunicação apresentada de acordo com os artigos 44 ou 45 seja admitida pela Comissão, será necessário: a) que hajam sido interpostos e esgotados os recursos da jurisdição interna, de acordo com os princípios de direito internacional geralmente reconhecidos [...]".

5 LANGFORT, Malcolm. Judicialização dos direitos econômicos, sociais e culturais no âmbito nacional: uma análise sócio jurídica. Revista Internacional de Direitos Humanos, São Paulo, v. 6, n. 11, p. 98 133, 2009.

6 É um conselho de estudos específicos que faz recomendações por temas, relativo ao caráter econômico. É um mecanismo de supervisão que faz envio de relatórios (por meio do material coletado do Estado, sociedade civil e ONGs) a Comissão de Direitos Humanos, e esta fará recomendações aos Estados membros, no caso do sistema Inter- Americano. As já mencionadas Convenções, aqui representadas pelo PIDESC, fazem parte do mecanismo convencional, representadas pelos seus respectivos comitês, que ajudam na produção dos relatórios e recebem denúncias. 
pela ONU teve influência direta na política dos estados-partes; especialmente com o advento do instrumento das Resoluções ${ }^{7}$, estas possibilitam a dinâmica (como característica essencial) de tais direitos.

Em se tratando da vinculação dos direitos em questão, houve a aprovação de dois pactos, com "espécies" de direitos separados, mas que pertencem ao mesmo gênero - Direitos Humanos. São eles: o Pacto Internacional de Direitos Civis e Políticos (PIDCP) e o Pacto Internacional de Direitos Econômicos, Sociais e Culturais (PIDESC), 1966. Devido a razões histórico-políti$\operatorname{cas}^{8}$ e pragmáticas ${ }^{9}$, na fase legislativa de aprovação, os instrumentos acima foram fragmentados pela Assembleia Geral das Nações Unidas para complementarem a DUDH de $1948^{10}$.

A noção era de que o PIDCP estabelecesse a obrigação do Estado de respeitar e garantir direitos, e o PIDESC precisaria da adoção de medidas com o máximo de recursos disponíveis, de forma progressiva, para atingir a finalidade do pacto. Os DESC foram vistos como mais substanciais e dependentes de mudanças estruturais, medidas regionais (obrigações positivas por parte dos Estados), o que não procede, visto que o PIDESC necessita de medidas negativas, como o direito dos pais de liberdade quanto a decidir a escola que fornecerão a seus filhos, art. 13 de tal pacto, assim como o direito de construir, filiar-se a sindicatos e grevar, art. $8^{\circ}$ (1) 'A' e 'D', do mesmo documento ${ }^{11}$.

7 São instrumentos publicados por organismos internacionais, podendo ter a forma de parecer, recomendação ou decisão, dependendo do ato que faz referência, possuem a função de suprir insuficiências básicas da comunidade internacional. As mais conhecidas são as da ONU, proferidas pela Assembleia Geral, ou pelo Conselho de Segurança, onde as proferidas pelas primeiras possuem a natureza jurídica de opinio juris, segundo a Corte Internacional de Justiça, (podendo ser base para costumes internacionais) e as segundas são de caráter vinculante, obrigatórias, aos estados membros.

8 TEREZO, Cristina Figueiredo. A atuaşão do sistema interamericano de proteção dos direitos humanos na defesa dos direitos econômicos, sociais e culturais. 2011. Tese (Doutorado em Direito) - Universidade Federal do Pará, Belém, 2011.

9 Por terem que demonstrar resultados em curto prazo, daí porque precisariam de métodos de implementação distintos, os DESC necessitariam de mudanças estruturais dos Estados membros, precisavam de um número de assinaturas e ratificação, e ambos os pactos eram desejados por um grande número de países.

10 TRINDADE, Antônio Augusto Cançado. Tratado de Direito Internacional dos Direitos Humanos. 2. ed. Porto Alegre: Sergio Antonio Fabris, 2003. v. 1. p. 640.

11 TRINDADE, Antônio Augusto Cançado. Tratado de Direito Internacional dos Direitos Humanos. 2. ed. Porto Alegre: Sergio Antonio Fabris, 2003. v. 1. p. 640.
Em contrapartida, os Direitos Civis e Políticos foram vistos como mais fáceis de supervisionar e implantar, bastando a adequação legislativa aos países aderentes (liberdade negativa). Tal argumento, porém, também é improcedente, visto que o PIDCP prevê, em seu art. $2^{\circ}$, a obrigação dos Estados de implementar, substantivamente, os direitos como o direito à vida e à proteção da criança, ou o direito civil à assistência judiciária na perspectiva do devido processo legal no acesso à justiça.

In most cases, however, the measures to be adopted are not specified in the Covenant and it is for each State to determine them in the light of the protection needs of children in its territory and within its jurisdiction. The Committee notes in this regard that such measures, although intended primarily to ensure that children fully enjoy the other rights enunciated in the Covenant, may also be economic, social and cultural $[\ldots]^{12}$.

A questão da divisão entre direitos civis e sociais, entretanto, vai mais além. Ela decorreu do aspecto ideológico que o período requeria em prol de uma união internacional com nações de ambos os polos do mundo da época: o bloco socialista (com os direitos sociais) e o capitalista (com os direitos civis) ${ }^{13}$, após o final da Segunda Guerra Mundial. O marco que traduz a importância da não divisão dos direitos acima destacados foi a Conferência de Teerã ${ }^{14}$, em 1968, ao adotar a Proclamação de Teerã, em seu parágrafo 13, o qual proclama, oficialmente, a indivisibilidade dos direitos.

Assim, para acompanhar as novas gerações de direitos não tutelados - à princípio - nas constituições de seus Estados, a Europa teve que se adequar, em 1995, e repensar em um Protocolo à Carta Social Europeia $^{15}$, a qual significasse colocar em pauta a possibilidade de procedimentos de reclamações coletivas,

12 General comment no. 17: Article 24 (Rights of the child), Committee of Human Rights, ONU, thirty fifth session, 1989.

13 Apesar desse conflito político que dificultou a assinatura imediata de tais pactos, a atribuição de cada "bloco" de direitos exclusivamente a cada polo geopolítico (capitalista e socialista) é reducionista, visto que a própria delegação americana apoiou a entrada dos direitos sociais no corpo da DUDH, em favor de um sistema único de monitoramento para todos os direitos, dividido em comitês com atribuições de receber denúncias de violações a tais garantias, segundo Terezo.

14 TRINDADE, Antônio Augusto Cançado. Tratado de Direito Internacional dos Direitos Humanos. 2. ed. Porto Alegre: Sergio Antonio Fabris, 2003. v. 1. p. 640.

15 TRINDADE, Antônio Augusto Cançado. Tratado de Direito Internacional dos Direitos Humanos. 2. ed. Porto Alegre: Sergio Antonio Fabris, 2003. v. 1. p. 640. 
complementando o sistema de relatórios ${ }^{16}$, para oportunizar a participação de atores sociais e organizações não governamentais (ONGs, organizações nacionais e internacionais), por meio de reclamações coletivas para proteger substantivamente os direitos sociais. Essa foi uma medida de compatibilizar a Convenção Europeia de Diretos Humanos (1950) com as medidas assecuratórias de deveres positivos do Estado, como a intervenção do ente para a garantia de acesso à justiça, o que inclui adentrar no âmbito do direito público ou social ${ }^{17}$. O fato é que essas medidas são consolidadas na jurisprudência de tal corte.

Com o Protocolo de São Salvador ${ }^{18}$ no continente americano, em 1988 (em vigor desde 1999), deu-se preferência para os DESC, já que a Convenção Americana de Direitos Humanos de 1969 resume os direitos sociais em seu art. 26, "desenvolvimento progressivo".

O Protocolo de São Salvador foi pensado por meio de um Relatório Anual ${ }^{19}$, 1985-1986. Os DESC, no Protocolo de São Salvador, preocupam-se com o direito a um nível de vida adequado, oportunizado pelo exercício dos direitos ao trabalho (art. 6; art.7, condições justas e equitativas de trabalho), à educação (art. 13), à saúde (art. 10), à alimentação adequada (art. 12) e à previdência social (art. 9).

Assim, o mecanismo de controle da supervisão de tais direitos está previsto no art. 42 do respectivo protocolo, que determina aos Estados partes submeterem anualmente às Comissões de Executivas do CIES (Conselho Interamericano Econômico e Social) e do CIECC (Conselho Interamericano para Educação e Cultura) relatórios a fim de tutelar a garantia dos direitos previstos em tal norma ${ }^{20}$.

Como busca de proteção mais eficaz no mundo, os DESC possuem um Comitê específico (CDESC) em que todos os Estados Partes no PIDESC são obrigados a submeter-lhes informes regulares, realizando, cons-

16 Mecanismo de supervisão da CEDH.

17 TRINDADE, Antônio Augusto Cançado. Tratado de Direito Internacional dos Direitos Humanos. 2. ed. Porto Alegre: Sergio Antonio Fabris, 2003. v. 1. p. 640.

18 TRINDADE, Antônio Augusto Cançado. Tratado de Direito Internacional dos Direitos Humanos. 2. ed. Porto Alegre: Sergio Antonio Fabris, 2003. v. 1. p. 640.

19 Informe Anual de la Comissión Interamericana de Derechos Humanos, OEA/CIDH.

20 TRINDADE, Antônio Augusto Cançado. Tratado de Direito Internacional dos Direitos Humanos. 2. ed. Porto Alegre: Sergio Antonio Fabris, 2003. v. 1. p. 640. tantemente, decisões relevantes, para manter o objetivo do PIDESC e dar eficácia ao sistema de relatórios ${ }^{21}$, a fim de saber das conquistas, recomendações, sugestões e das dificuldades que impedem a eficácia do documento referido acima, art. 21 do PIDESC.

No Brasil, há o relatório "O Brasil e o Pacto Internacional de Direitos Econômicos, Sociais e Culturais Relatório da Sociedade Civil sobre o Cumprimento, pelo Brasil, do Pacto Internacional de Direitos Econômicos, Sociais e Culturais", que trata dos direitos contemplados pelo PIDESC: 1. Povos indígenas, remanescentes de quilombos e outras minorias; 2. Meio ambiente e desenvolvimento sustentável; 3. Discriminação e desigualdades; 4. Gênero; 5. Situação agrária; 6. Desenvolvimento econômico próprio; 7. Trabalho e Sindicalização; 8. Previdência social; 9. Descanso e lazer; 10. Família; 11. Saúde; 12. Alimentação; 13. Criança e adolescente; 14. Educação; 15. Cultura; 16. Moradia.

A natureza das obrigações dos países que aderem ao pacto em questão, incluindo o Brasil (ratificado em 1992), é progressiva e imediata, ou seja, a "obrigação de adotar medidas" imediatamente, art. 23 do PIDESC ${ }^{22}$.

Nesse ínterim, um dos compromissos, bastante relevante para o contexto sociopolítico brasileiro nos últimos anos, constitui, justamente, as "obrigações mínimas"23, consagradas pelo PIDESC. Isso signifi-

21 No Brasil, foi criada a Coordenação Nacional formada por entidades (OAB, Procuradoria Federal dos Direitos do Cidadão, Movimento Nacional de Direitos Humanos, CNBB, Centro de Proteção Internacional de Direitos Humanos, Anistia Internacional, INESC, Marcha Global contra o Trabalho Infantil, Ágora) e é coordenada pela Comissão de Direitos Humanos da Câmara dos Deputados. A comissão definiu o cronograma de trabalho e a metodologia do relatório, de acordo com as orientações do Comitê da ONU. Tem como funções acompanhar a constituição e os trabalhos dos Grupos Temáticos e Grupos de Audiências Públicas; sistematizar o texto final do relatório a partir dos dados e análises obtidas. Os Grupos Temáticos são constituídos por técnicos e representantes de entidades que atuam nas 17 áreas correspondentes aos direitos contemplados no PIDESC. Sua função é identificar as organizações não-governamentais e governamentais em seus respectivos setores, obter dados, elaborar análises e sistematizar o relatório temático, além de participar da redação final do relatório do PIDESC.

22 O protocolo facultativo ao PIDESC, inaugurou a possibilidade de oferecer denúncia individual ao CDESC, daí os DESC passam a ser direta e individualmente exigíveis no sistema ONU, desde 2013 para os países que o assinaram (Uruguai, Argentina, Bolívia, BósniaHerzegovina, El Salvador, Equador, Eslováquia, Espanha, Mongólia e Portugal). LEÃO, Renato Zerbini Ribeiro. O acesso direto dos indivíduos ao Comitê de Direitos Econômicos, Sociais e Culturais da ONU. Universitas Relaçoes Internacionais, Brasília, v. 11, n. 1, p. 29-38, jan./jun. 2013.

23 É um núcleo mínimo de direitos que os Estados membros do 
ca que, em casos de grave crise econômica ${ }^{24}$, quando não se pode cumprir todos os direitos de tal pacto, fica a cargo do Estado o ônus de provar que o "máximo dos recursos disponíveis" ${ }^{25}$ foram utilizados, devendo o ente assegurar os setores mais vulneráveis mediante programas de baixo custo, assim como provar quando este se encontra impossibilitado de cumprir com suas obrigações por razões externas, mesmo após infrutífera busca de auxílio internacional ${ }^{26}$. Os recursos são tan-

PIDESC devem assegurar para garantir as necessidades básicas de cada indivíduo, pelo parágrafo 25 do princípio de Limburgo, 1986: “ States parties are obligated regardies of the level of economic development, to ensure respect for minimum subsistence rights for all". 24 TRINDADE, Antônio Augusto Cançado. Tratado de Direito Internacional dos Direitos Humanos. 2. ed. Porto Alegre: Sergio Antonio Fabris, 2003. v. 1. p. 640.

25 General comment n. 3, Comittee on Economic, Social and Cultural Rights - Report on the Fifth Session, 1990: "NEPAL. 521. The Committee notes with appreciation that Nepal signed in 1996 a technical cooperation project and a memorandum of understanding with the Office of the United Nations High Commissioner for Human Rights [...] to execute the National Human Rights Action Plan in accordance with the Vienna Declaration and Programme of Action. $10^{\circ}$. [...] 527. The Committee takes note that the efforts of the State party to comply with its obligations under the Covenant are impeded by the high rate of population growth, the slow-down in economic growth, foreign debt, the effect of some aspects of the structural adjustment programmes it has adopted as well as the Maoist insurgency, which have negatively affected the enjoyment of economic, social and cultural rights by the population, and especially the most vulnerable and marginalized groups of society. The Committee strongly recommends that Nepalís obligations under the Covenant be taken into account in all aspects of its negotiations with international financial institutions, such as IMF, the World Bank and WTO, in order to ensure that economic, social and cultural rights, particularly of the most vulnerable groups, are duly protected. 555 . The Committee urges the State party to continue to develop and adopt a national plan of action for human rights, which would include economic, social and cultural rights, in accordance with the Vienna Declaration and Programme of Action and in the context of a participatory, open and consultative process. The Committee also requests the State party to annex a copy of the plan to its second periodic report." (Grifo nosso).

26 O documento que garante o mínimo e a impossibilidade de escusa do Estado perante violações à garantia do mínimo é o parágrafo 10 do General comment n.3, Comitee on DESC: “[...] Committee is of the view that a minimum core obligation to ensure the satisfaction of, at the very least, minimum essential levels of each of the rights is incumbent upon every State party. Thus, for example, a State party in which any significant number of individuals is deprived of essential foodstuffs, of essential primary health care, of basic shelter and housing, or of the most basic forms of education is, prima facie, failing to discharge its obligations under the Covenant. If the Covenant were to be read in such a way as not to establish such a minimum core obligation, it would be largely deprived of its raison d'être. By the same token, it must be noted that any assessment as to whether a State has discharged its mini- to os existentes dentro do Estado Parte como aqueles disponibilizados pela cooperação internacional. Então, o direito a um recurso efetivo é, também, os recursos administrativos que devem ser acessíveis, não onerosos, rápidos e eficazes inclusive contando por último com a apelação judicial ${ }^{27}$.

A interação entre o Direito Internacional e o Direito Regional para dar eficácia aos Direitos Humanos é de extrema importância para análise, pois os Estados são fiscalizados pelos mecanismos de controle dos direitos previstos nos pactos dos quais fazem parte (quando assinam a competência contenciosa para julgamento nas cortes) perante a comunidade internacional: "é a supervisão internacional da compatibilidade dos atos internos dos Estados com suas obrigações internacionais de proteção" 28 , referente à responsabilização internacional dos Estados.

Outra prova de interferência é a submissão das normas internas à adequação do convencionado nos tratados internacionais, pela primazia das normas mais favoráveis às vítimas "a compatibilização e prevenção de conflitos entre as jurisdições internacional e nacional em matéria de direitos humanos" ${ }^{29}$, como meio de controle de convencionalidade, fato que flexibiliza, em caráter constitucional, a soberania dos Estado Nação, mediante a transcendência ao direito estatal.

Tornando, assim, o Princípio da Soberania Estatal como responsabilidade, segundo Jónatas Machado:

[...] parece verificar-se uma tendência internacional no sentido de afirmação do modelo de "Estado de direito, democracia e direitos humanos", como princípio de direito internacional. Alguma doutrina

mum core obligation must also take account of resource constraints applying within the country concerned. Article 2 (1) obligates each State party to take the necessary steps 'to the maximum of its available resources'. In order for a State party to be able to attribute its failure to meet at least its minimum core obligations to a lack of available resources it must demonstrate that every effort has been made to use all resources that are at its disposition in an effort to satisfy, as a matter of priority, those minimum obligations." (Grifo nosso).

27 LEÃO, Renato Zerbini Ribeiro. O Acesso direto dos indivíduos ao Comitê de Direitos Econômicos, Sociais e Culturais da ONU. Universitas Relações Internacionais, Brasília, v. 11, n. 1, p. 29-38, jan./jun. 2013.

28 TRINDADE, Antônio Augusto Cançado. Tratado de Direito Internacional dos Direitos Humanos. 2. ed. Porto Alegre: Sergio Antonio Fabris, 2003. v. 1. p. 640.

29 TRINDADE, Antônio Augusto Cançado. Tratado de Direito Internacional dos Direitos Humanos. 2. ed. Porto Alegre: Sergio Antonio Fabris, 2003. v. 1. p. 640. 
considera que, partindo da afirmação do indivíduo como unidade primária e sujeito por excelência do direito internacional, a qualidade de Estado de direito democrático de direitos fundamentais deveria ser considerada pela comunidade internacional, como critério de legitimação da própria existência de um Estado enquanto tal. Neste sentido aponta a concepção de soberania como responsabilidade.

Nesse sentido, Flávia Piovesan analisa que é uma "abertura jurídica interna ao sistema internacional de proteção dos Direitos Humanos"30, em que a prevalência de tal princípio rege o Brasil no âmbito internacional de forma a vinculá-lo (pacta sunt servanda ${ }^{31}$ ) às normas internacionais dos Direitos Humanos, assim como a integração plena delas na esfera nacional, e de adotar posições políticas contrárias aos Estados em que tais direitos sejam desrespeitados.

O autor Mazzuoli considera, acertadamente, que a norma interna tem de estar em conformidade material com os tratados de direitos humanos internacionais, incluindo, assim, os tratados ratificados antes de 2004 (o Pacto de São José, o PIDCP e o PIDESC) por meio do controle difuso, já garantido pela CF de 88 .

O fundamento do princípio pro homine, art. $4^{\circ}$, II da $\mathrm{CF}$, que é um princípio geral de direito internacional responsável por garantir a norma mais favorável ao ser humano em meio a uma situação jurídica real ${ }^{32}$; decorre de dois fundamentos, dignidade da pessoa humana e da prevalência dos direitos humanos, os quais são condition sine qua non do Estado Brasileiro.

Segundo Mirely Delmas Martir, os Direitos Humanos internacionais possuem limites — apenas alguns raros possuem proteção absoluta ou quase absoluta. A última ocorre com relação ao direito à vida, visto que a pena de morte e da legítima defesa é justificável nos ca-

30 PIOVESAN, Flávia. Direitos humanos e direito constitucional internacional. 12. ed. São Paulo: Saraiva, 2011. p. 673.

31 Faz-se a ressalva de que os tratados internacionais podem positivar costumes já aplicados no direito internacional. Além disso, a relação de aplicação das normas é entre Estados partes, que consentiram expressamente com a adoção, por meio da ratificação da aprovação no Congresso Nacional de um acordo assinado pelo presidente da república (art. 84, VIII c/c. art. 49, I CF/88), salvo os preceitos dos tratados que decorrem dos costumes internacionais já incorporados internacionalmente, de acordo com a Convenção de Viena de 1969. Ainda no mesmo sentido, o art. 27 da mesma ressalta que "uma parte não pode invocar princípios de direito interno como justificativa para o não cumprimento do tratado".

32 MAZZUOLI, Valério de Oliveira. Teoria geral do controle de convencionalidade no direito brasileiro. Revista de Informação Legislativa, Brasília, ano 46, n. 181, p. 113-139, jan./mar. 2009. sos de guerra, art. $4^{\circ}$ do PIDCP; já referente à proteção absoluta tem-se a proibição da tortura, dos tratamentos desumanos ou degradantes, da escravidão e servidão, expulsões coletivas de estrangeiros, todos esses referentes à dignidade inerente à pessoa (prevista no art. $1^{\circ} \mathrm{da}$ DUDH, 1948, e nos pactos da ONU, de 1966).

A dignidade faz referência ao irredutível humano; é a exigência ética proibida de ultrapassar, em que a violência é um ato de negação do humano e, mais grave que o atentado à vida é o atentado à dignidade, pois essa é o que permite o homem se elevar/expressar para além das questões biológicas. Segundo Jean Ladrière, a tortura $^{33}$ é a tentativa de reduzir o corpo ao sofrimento e levar junto a consciência; é uma forma de destruição metafísica seguida da destruição física corolário do direito à vida. Portanto, para Martir os direitos de liberdade com relação à greve necessitam da análise da matéria econômica e social. Em suas análises do TEDH, conclui que este julga sem dividir os direitos, visto que a dignidade não se divide, e por isso a extrema pobreza e a exclusão social consistem em violações da dignidade — o direito ao desenvolvimento é universal e inalienável, como parte integrante dos direitos fundamentais da pessoa humana ${ }^{34}$.

Em seguida à Emenda Constitucional 45, pela inclusão do art. $5^{\circ}, \$ 3$, os tratados de direitos humanos internacionais passaram a ser formalmente constitucionais, com status equivalente a emendas constitucionais, quando aprovados com o quórum qualificado, configurando o controle de convencionalidade ${ }^{35}$, que consiste na compatibilização da produção normativa nacional com os tratados ratificados acima mencionados. Tais tratados, equivalentes a emendas, sujeitam as normas infraconstitucionais ao controle concentrado (ADIN, ADPF, ADCO) de constitucionalidade.

Em 2008, no HC 87.585-8/ TO, o Ministro Celso de Mello reconheceu o valor constitucional dos tratados de direitos humanos internacionais, independentemente da aprovação legislativa qualificada, por uma questão de primazia hierárquica em face aos tratados internacionais de direitos humanos a antinomias no direito interno,

33 MARTY, Mireille Delmas. Por um direito comum. São Paulo: Martins Fontes, 2004. p. 306.

34 MARTY, Mireille Delmas. Por um direito comum. São Paulo: Martins Fontes, 2004. p. 306.

35 MAZZUOLI, Valério de Oliveira. Teoria geral do controle de convencionalidade no direito brasileiro. Revista de Informação Legislativa, Brasília, ano 46, n. 181, p. 113-139, jan./mar. 2009. 
consagrando, assim, a aplicação do princípio internacional pro bomine $e^{36}$.

Já os tratados internacionais comuns, ratificados pelo Brasil, possuem status supralegal, inferior ao da CF, mas superior ao das leis internas, por não poderem ser revogados por lei infraconstitucional interna posterior, noção essa prevista no art. 98 do CTN. Assim, tem-se o controle de legalidade ${ }^{37}$.

O termo "dupla verticalidade" se refere ao controle de constitucionalidade de uma norma interna com a CF e ao controle de convencionalidade a que essa norma deve se adequar com relação aos tratados internacionais de direitos humanos ratificados; e, para efeitos de controle de convencionalidade, são incluídos, também, os precedentes proferidos pelos tribunais internacionais. A norma interna que seja constitucional, mas inconvencional, é vigente (refere-se a sua conformidade com o processo de produção legislativa: aprovação pelo Parlamento, sanção pelo Presidente da República, promulgação e publicação em Diário Oficial, esgotamento do prazo do vacatio legis), porém não é válida (faz referência ao conteúdo ser coerente com as normas internacionais) no ordenamento ${ }^{38}$. Quando uma lei interna anterior conflita com um tratado comum ratificado e em vigor (supralegalidade), ela é revogada de forma imedia$\mathrm{ta}^{39}$. Assim, ressalta-se que as normas que condicionam a produção interna são, também, de cunho substancial, como o Princípio da Igualdade e a Preponderância dos Direitos Fundamentais ${ }^{40}$.

A CF trata da compatibilidade das leis no âmbito dos direitos expressos por ela, art. $5^{\circ}, \$ 2^{\circ}$, que incluem os direitos fundamentais expressos (direitos e garantias

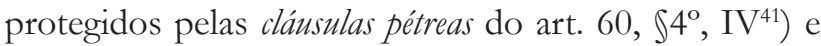

36 MAZZUOLI, Valério de Oliveira. Teoria geral do controle de convencionalidade no direito brasileiro. Revista de Informaşão Legislativa, Brasília, ano 46, n. 181, p. 113-139, jan./mar. 2009.

37 MAZZUOLI, Valério de Oliveira. Teoria geral do controle de convencionalidade no direito brasileiro. Revista de Informação Legislativa, Brasília, ano 46, n. 181, p. 113-139, jan./mar. 2009.

38 MAZZUOLI, Valério de Oliveira. Teoria geral do controle de convencionalidade no direito brasileiro. Revista de Informação Legislativa, Brasília, ano 46, n. 181, p. 113-139, jan./mar. 2009.

39 MAZZUOLI, Valério de Oliveira. Teoria geral do controle de convencionalidade no direito brasileiro. Revista de Informação Legislativa, Brasília, ano 46, n. 181, p. 113-139, jan./mar. 2009.

40 MAZZUOLI, Valério de Oliveira. Teoria geral do controle de convencionalidade no direito brasileiro. Revista de Informação Legislativa, Brasília, ano 46, n. 181, p. 113-139, jan./mar. 2009.

41 Que inclui não só os direitos individuais, como também os econômicos, sociais e culturais por uma interpretação teleológica, os direitos implícitos decorrentes do regime e dos princípios que devem ser compatíveis aos direitos previstos nos tratados (os quais não estão nem expressos nem implícitos na CF).

A Constituição brasileira não possui regra específica para o embate entre dualismo ou monismo. Segundo Mazzuoli, no Brasil, vivencia-se a Teoria do Dualismo Moderado, em que o direito internacional público e o direito interno são dois ordenamentos jurídicos distintos. Em decorrência disso, é necessário um ato formal de internalização dos tratados, como um decreto ou um regulamento ${ }^{42}$ para a garantia dos direitos fundamentais, de acordo com o art. $5^{\circ}$, $\$ 1$ e $\$ 3$ da $\mathrm{CF} / 88$, com o fim de integrar os tratados ratificados de direitos humanos e aplicá-los no plano do Ordenamento Jurídico interno. Devido a tal fato, não se tem no Brasil a soberania estatal absoluta, pelo Princípio da Prevalência dos Direitos Humanos na sua Carta Magna.

De acordo com Mazzuoli, atribui-se o valor de norma constitucional fundamental à previsão constitucional dos DESC, visto que não podem ter sua aplicação diminuída, deve ser dada a máxima eficácia à previsão constitucional, já que os pactos internacionais aprovados pelas Nações Unidas, a DUDH, a Carta da ONU, são considerados normas de jus cogens ${ }^{43}$ conjunto de normas internacionais costumeiras inderrogáveis ${ }^{44}$, de caráter imperativo referente aos direitos mais essenciais ao homem ${ }^{45}$. Ademais, o art. $5^{\circ}, \S 3^{\circ}$ da CF $/ 88$ atribui aos tratados internacionais de direitos humanos o caráter de cláusula pétrea e não podem ser abolidos por outra emenda constitucional, art. $60, \S 4^{\circ} \mathrm{da} \mathrm{CF} / 88^{46}$.

Outra observação esclarecedora é a de que não há substituição do Ordenamento Jurídico interno. As Cortes Europeia e Interamericana de Direitos Humanos não são um grau recursal, ou substitutivas da jurisdição regional; fato é que precisa haver o esgotamento dos

segundo a doutrina considera-se os "direitos fundamentais".

42 Não há previsão na CF de algum procedimento formal de internalização de tratados, mas o STF se posiciona no sentido da necessidade de um decreto de execução presidencial.

43 É um núcleo de normas que criam obrigações erga omnes, previstas art. 53 e 64 da Convenção de Viena sobre o Direito dos Tratados, de 1969.

44 BAPTISTA, Eduardo Correia. Ius Cogens em direito internacional. Lisboa: Lex, 1997. p. 375.

45 PIOVESAN, Flávia. Direitos humanos e direito constitucional internacional. 12. ed. São Paulo: Saraiva, 2011. p. 673.

46 PIOVESAN, Flávia. Direitos humanos e direito constitucional internacional. 12. ed. São Paulo: Saraiva, 2011. p. 673. 
recursos internos (tal Estado tem a obrigação de conhecer e interpretar as normas internacionais) para que um caso seja levado a tais organismos de supervisão (subsidiária, a qual julga baseando-se em jurisprudências internacionais, tratados e doutrina respectivos), quando se verificar uma possível violação das obrigações internacionais de direitos humanos pelos Estados Partes nas suas decisões judiciais e administrativas ${ }^{47}$.

Ainda nesse interim, há os mecanismos de "garantia coletiva" à proteção dos direitos em questão, por meio de petições interestatais, em que um órgão de supervisão internacional pode ser acionado a verificar os atos jurídicos, normativos e administrativos de outro Estado Parte $^{48}$. Assim como há, também, o direito de petição

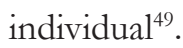

As limitações, restrições, devem ser previstas em lei, justificadas pelo Estado, em casos excepcionais ${ }^{50}$, para o interesse da sociedade complementada com a democracia, a fim de não se incorrer em arbitrariedades. A CADH é autoaplicável, como direito de resposta a uma obrigação internacionalmente exigível ${ }^{51}$, consagrada no art. $2^{\circ}$ da mesma, de adotar medidas para fazerem valer os direitos nela mencionados, se já não existirem medidas legislativas ou administrativas no próprio ordenamento interno.

Nesse sentido, houve a criação do PNDH-3 ${ }^{52}$ no

47 TRINDADE, Antônio Augusto Cançado. Tratado de Direito Internacional dos Direitos Humanos. 2. ed. Porto Alegre: Sergio Antonio Fabris, 2003. v. 1. p. 640.

48 Previsto no art. 45 da CADH e no art. 41 do PIDCP.

49 Previsto no art. 44 da CADH.

50 TRINDADE, Antônio Augusto Cançado. Tratado de Direito Internacional dos Direitos Humanos. 2. ed. Porto Alegre: Sergio Antonio Fabris, 2003. v. 1. p. 640.

51 TRINDADE, Antônio Augusto Cançado. Tratado de Direito Internacional dos Direitos Humanos. 2. ed. Porto Alegre: Sergio Antonio Fabris, 2003. v. 1. p. 640.

52 Como produto da implementação da Ação n ${ }^{\circ} .10$ da Declaração e Programa de Ação de Viena, Conferência Mundial sobre Direitos Humanos, 1993: "A Conferência Mundial sobre Direitos Humanos reafirma o direito ao desenvolvimento, conforme estabelecido na Declaração sobre o Direito ao Desenvolvimento, enquanto direito universal e inalienável e parte integrante dos Direitos $\mathrm{Hu}$ manos fundamentais.

Conforme estabelecido na Declaração sobre o Direito ao Desenvolvimento, a pessoa humana é o sujeito central do desenvolvimento. O desenvolvimento facilita o gozo de todos os Direitos Humanos, mas a falta de desenvolvimento não pode ser invocada para justificar a limitação de Direitos Humanos internacionalmente reconhecidos. Os Estados devem cooperar entre si para assegurar o desenvolvimento e eliminar os obstáculos que lhe sejam colocados. A comunidade internacional deve promover uma cooperação internacional efetiva com vista à realização do direito ao desenvolvimento e à
Brasil, (um aperfeiçoamento dos PNDH1 e PNDH2), sendo produto da $11^{a}$ Conferência Nacional de Direitos Humanos, em 2008, em que a sociedade civil organizada e o poder público decidiram consolidar a promoção de tais direitos. O PNDH-3 possui seis eixos orientadores, subdivididos em vinte e cinco diretrizes e oitenta e dois objetivos estratégicos, assim como Convenções Nacionais temáticas, Planos e Programas do Governo Federal, Tratados internacionais ratificados pelo Estado, Recomendações dos Comitês de Monitoramento de Tratados da ONU e de Relatórios Especiais que reformulam os planos anteriores.

É importante salientar, ainda, que os mecanismos de controle e monitoramento das violações de Direitos Humanos prescindem do diálogo público. Somente assim se consegue, com eficácia, as consequências do instituto "power of shame", que é o procedimento da CUDH responsável por forçar o estado a cumprir com suas recomendações, visto que seu nome estará "marcado" e "envergonhado" perante a comunidade internacional, acarretando consequências negativas para esses, de tal forma reduzindo o número de futuras violações e condenações.

Com todas as implementações legais e administrativas, prevalece, substancialmente, a norma mais favorável à vítima. Isso significa que, independentemente da hierarquia que as normas possuem internamente no país, há a supremacia de tal princípio.

Assim, se um país membro possuir leis mais favoráveis até mesmo do que as garantidas nos pactos internacionais já mencionados, tal ente não pode restringir esses direitos "mais benéficos" 53 sob a justificativa de que tal tratado não os reconhece no mesmo nível de garantia (art. $5^{\circ} .2$ do PIDCP e art. $4^{\circ}$ do Pacto de São Salvador), visto que os próprios padrões internacionais de tutela a direitos não podem ser rebaixados, mas sim elevados ${ }^{54}$.

eliminação de obstáculos ao desenvolvimento.

O progresso duradouro no sentido da realização do direito ao desenvolvimento exige a adoção de políticas de desenvolvimento eficazes a nível nacional, bem como o estabelecimento de relações econômicas equitativas e a existência de um panorama econômico favorável a nível internacional. "

53 TRINDADE, Antônio Augusto Cançado. Tratado de Direito Internacional dos Direitos Humanos. 2. ed. Porto Alegre: Sergio Antonio Fabris, 2003. v. 1. p. 640.

54 TRINDADE, Antônio Augusto Cançado. Tratado de Direito Internacional dos Direitos Humanos. 2. ed. Porto Alegre: Sergio Antonio Fabris, 2003. v. 1. p. 640. 


\section{As CONSEQUÊNCIAS dos DESC COMO DIREITOS FUNDAMENTAIS}

As principais críticas aos direitos sociais como direitos fundamentais são de ordem estrutural: por serem aplicáveis apenas sob a luz do princípio da reserva do financeiramente possível; o fato dos mesmos necessitarem de positividade especificada para todas as espécies de demandas (visto que tais garantias somente seriam concedidas a um grupo de pessoas "necessitadas", portanto não seriam universais); e a indeterminabilidade do conteúdo constitucional de prever todos os ditos direitos dessa espécie (ou seja, vinculação fraca do poder público à norma constitucional). Tais análises impedem, segundo a crítica, o tratamento igualitário aos dois tipos de direitos civis e sociais ${ }^{55}$.

O Estado conta com a administração pública para organização de gastos por meio do sistema financeiro e orçamentário, com planejamentos de receitas e despesas. As carências materiais das pessoas perpassam os direitos sociais, os quais possuem um alto custo financeiro associado à criação e disponibilização de instituições, serviços e estruturas que forneçam acesso aos DESC. Estes estão sujeitos à limitação financeira em que um Estado, durante uma escassez moderada de recursos, acaba por vincular (ultra posse nemo obligatur) a previsão, a escolha legislativa e executiva de planejamento à prestação judicial.

A reserva do possível é definida como os bens que a sociedade pode exigir de forma razoável à administração, onde em cada caso concreto tem que se levar em conta as circunstâncias específicas (relação entre necessidades e possibilidades das prestações), e a proporcionalidade ${ }^{56}$.

Ainda nesse sentido, o Estado, em típica situação de normalidade, não possui escassez financeira absoluta, mas sim prioridades de escolhas políticas com relação à distribuição e alocação de recursos dentre as várias opções públicas.

Em decorrência de tal fato, a crítica considerou os direitos sociais como dependentes da imposição parla-

55 NOVAIS, Jorge Reis. Direitos sociais: teoria jurídica dos direitos sociais enquanto direitos fundamentais. Coimbra: Editora Wolters Kluwer Portugal, 2010.

56 NOVAIS, Jorge Reis. Direitos sociais: teoria jurídica dos direitos sociais enquanto direitos fundamentais. Coimbra: Editora Wolters Kluwer Portugal, 2010. mentar (o titular do poder político e o legislador), em que o juiz estaria usurpando a função destes se definisse a distribuição de recursos no processo, invadindo a esfera da separação de poderes. Nessa situação, os direitos fundamentais não ficariam a cargo exclusivamente do interesse parlamentar. Contudo, o juiz só pode decidir sobre direitos fundamentais se assim o legislador definiu, segundo Alexy ${ }^{57}$.

Todos os direitos são positivos, segundo Sunstein e Holmes ${ }^{58}$, inclusive os de liberdade, e todos demandam de redistribuição de riqueza social. Portanto, estes dependem de responsabilidade como fruto de negociação/opção social; por isso, são dependentes das instituições públicas. Os direitos são, para além da sua fundamentação moral, descritivos no sentido de possuírem "dentes" que possibilitam a utilização do aparato estatal, dos remédios jurídicos previstos no ordenamento para que se garantam e efetivem tais direitos de forma concreta - é o seu viés pragmático complementando a fundamentação ética. Qualquer direito negativo precisa de um sistema judicial e administrativo que garanta o seu remédio, ou seja, também depende de custos, gastos e despesas $^{59}$.

Com relação aos remédios dos DESC, se tem avanços no sentido de procurar alternativas, para além das costumeiras indenizações, restituições, ilícitos cíveis, e declaração de ato inválido. Os tribunais exigem certo curso de ação para o estado reparar determinado dano. Além das cortes judiciais serem mais dialogais, elas emitem ordens de acompanhamento de decisões anteriores, a fim de garantir que os pleitos da decisão favorável sejam garantidos. Isso ocorre muito na esfera internacional de supervisão das decisões das cortes internacionais, mediante o sistema de relatórios ${ }^{60}$.

Além dos remédios, há outras formas de o Estado intervir como a manutenção da segurança pública para

57 NOVAIS, Jorge Reis. Direitos sociais: teoria jurídica dos direitos sociais enquanto direitos fundamentais. Coimbra: Editora Wolters Kluwer Portugal, 2010.

58 GALDINO, Flávio. Introdução à teoria dos custos dos direitos: direitos não nascem em arvores. Rio de Janeiro: Lumen Juris, 2005. p. 380 .

59 NOVAIS, Jorge Reis. Direitos sociais: teoria jurídica dos direitos sociais enquanto direitos fundamentais. Coimbra: Editora Wolters Kluwer Portugal, 2010.

60 LANGFORT, Malcolm. Judicialização dos direitos econômicos, sociais e culturais no âmbito nacional: uma análise sócio jurídica. Revista Internacional de Direitos Humanos, São Paulo, v. 6, n. 11, p. 98-133, 2009. 
manter a propriedade privada de um indivíduo titular. Mesmo que o último seja um direito "negativo", ele precisa da proteção positiva do Estado para a sua proteção, como um aparato contínuo normativo, produzido por juízes e legisladores, da proteção contínua dos agentes governamentais como bombeiros, policiais, dentre outros que são mantidos e pagos pelo ente. Assim como todos os outros direitos de liberdade positivados na CF/ 88 estão passíveis da mesma relação, todos os direitos fundamentais são positivos por possuírem custos.

O Estado só existe em razão dos recursos econômicos e financeiros arrecadados dos indivíduos; o fluxo orçamentário é necessário para existência concreta dos direitos. O estudo dos custos serve para redimensionar a atenção (escolha pública com o que gastar) para os direitos em determinada sociedade, visto que os recursos são insuficientes. Então, a ideia de analisar os custos e benefícios pode ofertar uma solução sistêmica, no âmbito do direito público, na perspectiva da compreensão econômica das medidas judiciais.

Nem sempre serão utilizadas decisões standards, para não excluir da análise de ponderação os efeitos práticos para a pessoa no caso concreto, o que pode significar a negação concreta do mesmo direito a várias outras pessoas em outros casos.

Ainda a respeito da reserva do possível, a efetividade e eficácia são noções distintas. É nesse ponto onde se encaixa a complementariedade entre as espécies de direitos já citados, pois é importante garantir, juridicamente, um direito, assim como criar condições fáticas (reais) que permitam a todos o acesso ao bem protegido. Tanto os direitos liberais precisam de eficácia, para serem garantidos, quanto os sociais precisam de reconhecimento normativo, flexível, para serem economicamente implantados pelo Estado de forma célere.

No que concerne às propostas de ponderação para resolução de conflitos entre direitos sociais como solução para os conflitos judiciais, existe margem para o legislador ordinário ou o órgão judicial se esquivarem de um direito social fundamental, pois este pode ser sempre restringido com a justificativa da defesa de outro bem que seja igualmente digno de proteção ${ }^{61}$.

Apesar de a reserva do possível ter como conse-

61 NOVAIS, Jorge Reis. Direitos sociais: teoria jurídica dos direitos sociais enquanto direitos fundamentais. Coimbra: Editora Wolters Kluwer Portugal, 2010. quência a possível restrição de direitos, não é escusável a constante utilização dessa restrição, visto que não é constitucionalmente admissível ${ }^{62}$, pois há a proibição do excesso de "restrições".

Considerando que os direitos liberais estão condicionados à ponderação e ao limite financeiro em certos casos, e os sociais estão condicionados à ponderação e à reserva do financeiramente possível, cabe ao judiciário $^{63}$ a última palavra, respeitando o limite orçamentário. Desse modo, o legislador ordinário faz escolhas políticas orçamentárias, e o juiz fica vinculado às omissões daqueles com as ausências das previsões dos direitos sociais.

Por outro lado, como visto anteriormente, os direitos são complementares, pois não há a garantia dos direitos liberais sem um mínimo de direitos matérias, ou seja, os DESC acabam fazendo parte (integrante) dos próprios Direitos Civis e Políticos. Então, a reserva do possível limita, em igual medida, os direitos liberais ${ }^{64}$. Dessa forma, o problema de escolha política ordinária também afeta os direitos liberais, como o direito à vida ${ }^{65}$ que precisa de um mínimo material para ser garantido ${ }^{66}$.

62 NOVAIS, Jorge Reis. Direitos sociais: teoria jurídica dos direitos sociais enquanto direitos fundamentais. Coimbra: Editora Wolters Kluwer Portugal, 2010.

63 É possível a intervenção do Judiciário para a recomposição da ordem jurídica toda vez que houver violações por ação ou omissão do Poder Público, visto que o Estado existe para atender ao bem comum, pela satisfação espontânea dos direitos fundamentais. Não é seria válida a invocação do princípio da separação dos poderes para a não apreciação da pretensão do titular do direito fundamental social. ANDRADE, Diogo de Calasans Melo. Políticas públicas, mínimo existencial e Poder Judiciário: a questão do direito à moradia. Revista Brasileira de Políticas Públicas, Brasília, v. 6, n. 1, p. 150-165, 2016.

64 NOVAIS, Jorge Reis. Direitos sociais: teoria jurídica dos direitos sociais enquanto direitos fundamentais. Coimbra: Editora Wolters Kluwer Portugal, 2010.

65 No caso Vilagran Morales e outros contra Guatemala, o Juiz Cançado Trindade Presidente da Corte Interamericana, entendeu que: "O dever do Estado de tomar medidas positivas se acentua precisamente em relação com a proteção da vida de pessoas vulneráveis e indefesas, em situação de risco, como são as crianças de rua. A privação arbitraria da vida não se limita, pois, ao ilícito de homicídio; se estende igualmente a privação do direito de viver com dignidade. Esta visão conceitua o direito a vida como pertencente, ao mesmo tempo, ao domínio dos direitos civis e políticos, assim como ao dos direitos econômicos, sociais e culturais, ilustrando assim a inter-relação e indivisibilidade de todos os direitos humanos". LIMA, Jayme Benvenuto Jr. Acesso aos sistemas global e regional de proteção dos direitos humanos: manual de direitos humanos internacionais. São Paulo: Loyola, 2002.

66 NOVAIS, Jorge Reis. Direitos sociais: teoria jurídica dos direitos sociais enquanto direitos fundamentais. Coimbra: Editora Wolters Kluwer Portugal, 2010. 
Assim, o Estado precisa atuar, positivamente, para garantir os direitos sociais o que, consequentemente, permitirá a melhor condição para o exercício dos direitos fundamentais de liberdade (civis e políticos).

Em seguida, a escolha do Estado em qual direito dedicar seus recursos é o que caracteriza a reserva do possível, visto que sempre há dinheiro, porém, nunca haverá dinheiro para determinados pleitos, já que, no caso, o legislador decidirá onde alocar cada recurso; por isso, existe a pressão para os assuntos envolvendo alocação de recursos tanto jurídica quanto politicamente.

Em casos regionais de recursos escassos há o dilema em saber qual a responsabilidade dos órgãos perante violações de direito. O juiz tem o papel de analisar se as circunstâncias são passiveis de generalização, pois um caso gera precedente para seus semelhantes, tal qual o Estado tem o dever de cumprir a decisão para com a sociedade. O que se pretende afastar é a ideia da generalização como escusa para cumprir obrigações constitucionais (incluindo os DESC), já que, em matéria de defesa, a administração se limita, constantemente, a alegar a impossibilidade material de generalização igualitária da prestação social, porém, negar isso seria negar a própria qualidade de direito ${ }^{67}$.

No Brasil, com a vinculação constitucional delimitando os princípios a serem seguidos pelo judiciário e com a crescente vinculação a tratados internacionais de Direitos Humanos (em especial ao PIDESC), o juiz tem que interpretar a decisão do caso de acordo com as orientações superiores ${ }^{68}$ (justiciabilidade forte dos direitos positivos).

Em relação à legislação ordinária, quando restringe direitos na escolha de alocação de recursos, há a necessidade do controle da sua constitucionalidade, pois trata das parcelas de direitos fundamentais; por exemplo, a Constituição Brasileira garante a assistência material em casos de desemprego (seguro desemprego, art. 7, II $\mathrm{CF} / 88$ ), e posteriormente o legislador infraconstitucional criou o subsídio desemprego que integra o direito social fundamental, o qual, se for negado, estar-se-á a violar o direito fundamental.

67 NOVAIS, Jorge Reis. Direitos sociais: teoria jurídica dos direitos sociais enquanto direitos fundamentais. Coimbra: Editora Wolters Kluwer Portugal, 2010.

68 Decisões das instâncias superiores nacionais, e da responsabilidade assumida internacionalmente de respeito às normas internacionais de direitos humanos (legislações, costumes, princípios, jurisprudência, recomendações).
Em decorrência dos pontos já tratados neste artigo, faz-se essencial a análise do mínimo social, isto é, o quantum exigível das prestações. Segundo os críticos, não é possível este ser determinado por ponderações. Nesse sentido, o mínimo pode ser motivo/argumento para o Estado não se esforçar a garantir um progresso deste quando tem condições. Então, a interpretação que melhor define a tentativa de distribuição de bens materiais básicos a todos é: o Estado deve fazer o máximo possível com o mínimo progressivo.

Ao mínimo existencial aplica-se a noção de dupla função: prestacional (positiva) e defensiva (negativa), inerente aos direitos fundamentais em geral e aos direitos sociais em particular. O núcleo essencial, blindado contra toda e qualquer intervenção por parte do Estado e da sociedade, não é o mesmo em cada direito social (educação, moradia, assistência social, etc.), fazendo-se necessária a contextualização em cada oportunidade ${ }^{69}$.

Enquanto o mínimo fisiológico se constitui das condições materiais mínimas para uma vida condigna, no sentido da proteção às necessidades de caráter existencial básico, o mínimo existencial sociocultural, para além da proteção básica já referida, objetiva assegurar ao indivíduo um mínimo de inserção na vida social e cultural $^{70}$. Cabe aos tribunais decidir sobre esse padrão existencial mínimo, nos casos de omissão ou desvio de finalidade dos órgãos legiferantes. Tal "mínimo" não pode servir de pretexto para a redução ao aspecto meramente "vital", pois a dignidade implica dimensão ampla e sociocultural (relativa à essência/personalidade humana) que é igualmente considerada elemento nuclear a ser respeitado e promovido, razão pela qual prestações básicas em termos de direitos culturais estão inclusas no mínimo existencial ${ }^{71}$.

Consoante Alexy, doutrina utilizada na construção dos pilares democráticos brasileiros, os princípios são mandados de otimização que colidem num caso con-

69 SARLET, Ingo Wolfgang. Prestação jurisdicional, dignidade (da pessoa) humana, mínimo existencial e justiça constitucional: algumas aproximações e alguns desafios. Revista CEJUR / TJSC, v. 1, n. 1, p. 29-44, 2013.

70 SARLET, Ingo Wolfgang. Prestação jurisdicional, dignidade (da pessoa) humana, mínimo existencial e justiça constitucional: algumas aproximações e alguns desafios. Revista CEJUR / TJSC, v. 1, n. 1, p. 29-44, 2013.

71 SARLET, Ingo Wolfgang. Prestação jurisdicional, dignidade (da pessoa) humana, mínimo existencial e justiça constitucional: algumas aproximações e alguns desafios. Revista CEJUR / TJSC, v. 1, n. 1, p. 29-44, 2013. 
creto, resultando na prevalência de um princípio em detrimento de outro para se encontrar a solução ${ }^{72}$. Por conseguinte, rejeita-se a hierarquia entre princípios, visto que as suas dimensões de peso e proporcionalidade se dão conforme as circunstâncias do caso concreto. $\mathrm{O}$ termo "mandado de optimização" decorre dos princípios serem aplicados na sua maior medida possível ${ }^{73}$, como a maximização/optimização do mínimo existencial, mesmo que existam limitações fáticas (empíricas) tais como a limitação de recursos para a garantia do direito de saúde, e limitações jurídicas referentes aos limites do direito fundamental de um ser o direito fundamental do outro.

O caráter fundamental, nesse sentido, refere-se aos direitos constitucionalmente garantidos de forma implícita ou explicitamente. Se o direito internacional em matéria de Direitos Humanos é previsto no art. $4^{\circ} \mathrm{e}$ incisos da $\mathrm{CF} / 88$, então, seus princípios devem ser assegurados e optimizados no caso concreto. Dessa forma, quando se tem o embate, vivenciado pelos tribunais, entre direito à saúde (é princípio por ser um direito fundamental explicito, art. $196 \mathrm{CF}$ ) e o direito ao orçamento público, utilizado na defesa do estado (é princípio por ser um direito fundamental implícito) tem que se levar em conta a proporcionalidade, no caso prático, para se escolher qual adotar. Portanto, o mínimo é um conceito que deve ser interpretado da forma mais ambiciosa possível (visão maximalista), para não incorrer em justificações de limitação de direitos (visão minimalista), e se evitar que, em prol de certos direitos (aqueles escolhidos pelo legislador ordinário), outros direitos "sejam desnecessários".

Os direitos sociais são importantes, também, na sua dimensão negativa. O direito de non facere do Estado constitui garantia de direitos, de respeitar os direitos fundamentais. Consoante à liberdade negativa, há uma consequência: o direito ao não retrocesso do que já se está sendo realizado como proteção jurídica reforçada para não afetar o conteúdo dos direitos sociais, implícita no art. $2^{\circ}, 1$, PIDESC.

A realização progressiva dos Direitos Humanos, em geral, já constitui uma proibição implícita ao retrocesso. Dessa maneira, dentre os órgãos das Nações Uni-

72 ALEXY, Robert. Teoria e direito público: teoria dos direitos fundamentais. Tradução de Virgílio Afonso da Silva. 2. ed. São Paulo: Malheiros Editores, 2017. p. 670.

73 ALEXY, Robert. Teoria e direito público: teoria dos direitos fundamentais. Tradução de Virgílio Afonso da Silva. 2. ed. São Paulo: Malheiros Editores, 2017. p. 670. das, o Comitê dos DESC fica encarregado de vigiar a aplicação de tais direitos para se evitar que o mínimo existencial seja restringido ao mínimo vital, e o Estado não possa se escusar de responsabilidades por restringir direitos fundamentais.

A dignidade da pessoa humana é a garantia de uma existência que permita a "plena fruição dos direitos fundamentais, de modo especial, quando seja possível o pleno desenvolvimento da personalidade" ${ }^{\text {" }}$. Esse conteúdo dialoga, diretamente, com o mínimo existencial, o qual independe de expressa previsão legal na Constituição para poder ser reconhecido. O mínimo existencial é o núcleo dos direitos fundamentais onde se propõe assegurar a vida por meio do respeito à dignidade da pessoa humana com base na garantia dos direitos básicos socioculturais, e no Princípio da Igualdade, sendo este mínimo protegido contra intervenções estatais e da própria sociedade $\mathrm{T}^{75}$.

A Constituição brasileira, como a portuguesa, adota a noção dos direitos sociais como sendo direitos fundamentais expressamente garantidos. Assim, associa-se que o dever estatal é complexo, no sentido de abster-se com relação a direitos negativos e de intervir pela atuação positiva para a remoção de impedimentos do exercício de direitos (causados tanto por particulares quanto por entidades públicas, nacionais ou internacionais), em prol da garantia dos direitos fundamentais, tanto de cunho liberal como social. Já que as privações de direitos se tornam uma forma de exclusão de prerrogativas individuais elementares que deveriam ser certas, dentre elas está a área do campo político, econômico e social. Além da intervenção estatal preventiva, há também a intervenção em face de eventos fáticos: eventualidades naturais, catástrofes, riscos tecnológicos, entre outras que coloquem o cidadão em situação de risco ${ }^{76}$.

74 SARLET, Ingo Wolfgang. Prestação jurisdicional, dignidade (da pessoa) humana, mínimo existencial e justiça constitucional: algumas aproximações e alguns desafios. Revista CEJUR / TJSC, v. 1, n. 1, p. 29-44, 2013.

75 SARLET, Ingo Wolfgang. Prestação jurisdicional, dignidade (da pessoa) humana, mínimo existencial e justiça constitucional: algumas aproximações e alguns desafios. Revista CEJUR / TJSC, v. 1, n. 1, p. 29-44, 2013.

76 NOVAIS, Jorge Reis. Direitos sociais: teoria jurídica dos direitos sociais enquanto direitos fundamentais. Coimbra: Editora Wolters Kluwer Portugal, 2010. 


\section{UMA IDEIA DE JUSTIÇA NO AUMENTO DE LIBERDADES PARA O DESENVOLVIMENTO SOCIAL}

Amartya Sen utiliza-se da ideia de que uma teoria de justiça como um modelo menos injusto partiria da consideração de um espectador imparcial, da perspectiva do homem que se ausenta do vínculo com a posição (social) atual, a fim de realizar juízos "desinteressados". Nessa lógica, qualquer pessoa, tanto as pertencentes à sociedade analisada/grupo focal - denominada de imparcialidade fechada por John Rawls — quanto os de fora dela — denominada de imparcialidade aberta por Adam Smith — são essenciais para determinar quais os princípios da justiça a fim de atribuir direitos e deveres a serem obedecidos pelo grupo focal e de melhorar a distribuição de bens no modelo de justiça a ser adotado.

A posição original é pôr o homem sob o véu da ignorância do contrato social hipotético, em que este escolherá seus princípios básicos por meio de um prisma ausente de parcialidades de uma posição determinada, com o intuito de evitar ao máximo os benefícios de classes e objetivos pessoais. Em complementação a Rawls, Sen se utiliza de Smith para acoplar as vozes dos outros, externos, ao grupo que se analisa a fim de chegar a uma conclusão principiológica ainda mais justa. O objetivo é eliminar os princípios que só podem ser conhecidos a partir de uma posição específica previamente estipula$\mathrm{da}^{77}$; o fim é alcançar um equilíbrio reflexível, em que as opiniões coincidem, o qual está sujeito a perturbações até ser reequilibrado.

O que os homens veem não é desvinculado da posição em que estão, a objetividade posicional, é aquilo visto por qualquer pessoa a partir de uma posição específica. Conforme esse raciocínio, Amartya Sen procura relacionar a ética e a política com o interesse de quem está na posição específica ocupada, como forma de busca do interesse próprio devido a essa posição; por exemplo, o funcionário público que dá preferência ao interesse de seu filho em prol dos seus deveres civis, ou seja, a posição entre eles dá margem para ele tomar essa decisão.

A perspectiva da posição pode manter as pessoas limitadas a elas, como numa sociedade em que a mulher é, por tradição, subalterna, tem-se uma barreira para o

77 Se o observador soubesse que era "rico", iria defender o princípio de que vários tributos sociais são injustos, e o contrário seria concluído pelo mesmo se soubesse que era "pobre". aumento do número de mulheres cientistas. A necessidade de ir além da posição de observação se deve à superação de discriminações. É importante observar que isso se interliga com o estado das sociedades, categorizando os indivíduos somente por uma de suas identidades em detrimento de todas as outras ${ }^{78}$.

No entanto, mesmo adotando a ideia de que uma posição imparcial seria mais justa, a realidade nos leva a considerar que nem sempre as pessoas agem com a razão; caso contrário, tal modelo de justiça seria utópico. O que se procura é a capacidade de oportunizar a escolha racional à pessoa, deixando o indivíduo livre para raciocinar os seus atos e as consequências dele, assim como a dos outros ao seu redor; visto isso, essa capacidade, em outras palavras, é "o potencial de realizar várias combinações de funcionamentos que possamos comparar e julgar entre si com relação àquilo que temos razão para valorizar"

Amartya Sen se utiliza de uma alegoria lúdica, um mito indiano, a fim de explicar o que seria a justiça, Niti e Nyaya, sendo a primeira a "adequação organizacional quanto à correção comportamental”, já a segunda é complementária, mas está preocupada com "ao modo como emerge, em especial, a vida que as pessoas são realmente capazes de levar" ${ }^{\prime 80}$.

A felicidade, portanto, sobre a perspectiva de Nyaya, é um fator importante para transformar as liberdades em capacidades e em realizações, segundo a "Teoria das Capacidades", pois tanto os sucessos quanto os fracassos pessoais se relacionam com as realizações dos objetivos de cada um. Vale ressaltar que mesmo comparando a felicidade de um indivíduo em diferentes modelos de estado social, não é válida a comparação da felicidade de um com a de outro indivíduo. A felicidade está ligada com a identidade, por exemplo o secularismo que surge de interpretações políticas em busca de benefícios próprios pode acarretar em uma divisão sectária (demagogia sectária). Logo, reconhecer a multiplicidade de identidades é uma reflexão importante; a identidade religiosa é uma só ${ }^{81}$.

78 SEN, Amartya. Ideia de justiça. São Paulo: Companhia das Letras, 2011.

79 SEN, Amartya. Ideia de justiça. São Paulo: Companhia das Letras, 2011.

80 SEN, Amartya. Ideia de justiça. São Paulo: Companhia das Letras, 2011.

81 SEN, Amartya. Ideia de justiça. São Paulo: Companhia das Letras, 2011. 
As declarações éticas (Declaração de Independência dos EUA, declaração francesa dos direitos do homem e Universal de Direitos Humanos, de 1948) são convites para criações de novas legislações (regionais ou mais específicas), pois são frutos de conteúdos políticos distintos, resultados das vozes de pessoas e instituições, bem como a elaboração dessas declarações possuem redações de grupos que confluem com as instituições, que procuram afirmações éticas legalmente asseguradas ${ }^{82}$. Portanto, os Direitos Humanos são pretensões éticas associadas às liberdades, em que aquelas surgem mediante o debate racional, com a imparcialidade aberta, o que serve de inspiração a leis e até mobilizações sociais.

Esses direitos não são derivados da cidadania de qualquer país, são pretensões de todos os seres humanos. Nesse sentido, a necessidade de ouvir vozes diversas/externas à uma determinada cultura por meio da experiência do "espectador imparcial" não quer dizer aceitar todas as propostas, mas sim enriquecer a noção crítica do grupo estudado por meio de trocas de experiências, sendo essa noção até mesmo necessária para fortalecer o respeito a sua própria cultura.

A felicidade, mesmo que pessoal, também inclui o outro, não por questões utilitaristas, mas sim por simpatia. Uma pessoa utiliza de razão para se responsabilizar por um dever e também se envolve com interesses dos outros, por notar a sua importância em conseguir participar das realizações, das liberdades do outro ${ }^{83}$. Então, as pessoas acabam por se responsabilizar (em caráter geral) por impedir violações de direitos. É uma questão de caráter ético universal; é admitir que qualquer pessoa tem condições de fazer algo para impedir violações de direitos $^{84}$.

As questões éticas referentes ao desenvolvimento global e reivindicações estão vinculadas com o reconhecimento de aprimorar as capacidades humanas por meio dos direitos humanos. A crítica ao PIDESC por afirmar direitos de conteúdo sem exequibilidade, e por isso não aplicáveis, não é válida, pois se esta fosse requisito, todos os direitos (inclusive os de liberdades) seriam inaplicáveis, visto a impossibilidade de garantir a liberdade, a vida e a paz de todos. E é por causa do exposto

82 SEN, Amartya. Ideia de justiça. São Paulo: Companhia das Letras, 2011.

83 SEN, Amartya. Ideia de justiça. São Paulo: Companhia das Letras, 2011.

84 SEN, Amartya. Ideia de justiça. São Paulo: Companhia das Letras, 2011. que se faz ainda mais necessária a ação social.

Tal ideia de justiça preocupada com as injustiças extremas relaciona a fundamentação da expansão das liberdades individuais com o desenvolvimento econômico e social.

As liberdades, em Sen, são diversas; o ser humano as valora conforme a sua condição social, com o juízo da razão avaliatória, e a livre condição de agente da pessoa serve para possibilitar o desenvolvimento, a razão da eficácia.

Assim, existem liberdades substantivas referentes aos processos de ação e decisão e liberdades substantivas referentes às oportunidades que as pessoas necessitam para realizar o mínimo existencial, são essas as liberdades essenciais para serem consideradas na noção de capacidades. A capacidade é apenas um aspecto da liberdade relacionado com as oportunidades substantivas, a capacidade é a avaliação das vantagens e desvantagens de uma pessoa.

Nesse ínterim, a "Teoria da Capacidade", de Sen, busca a expansão das capacidades das pessoas em levar o tipo de vida que valorizam, que dependem das políticas públicas relativas à prestações positivas de direitos sociais, assim como da participação do povo. A última requer o elemento da liberdade individual (de ação e decisão) relacionado com as oportunidades reais que as pessoas possuem, os quais impactam no processo de desenvolvimento social; uma sociedade é avaliada pelas liberdades substantivas que seus membros gozam ${ }^{85}$.

Para Sen, a liberdade global se subdivide em liberdades instrumentais que possuem cunho político direitos políticos associados à democracia; cunho econômico, relativo às oportunidades para realizar o consumo, produção e trocas; cunho social, como a garantia da vida saudável, sem mortes prematuras, ou a participação política das pessoas por meio da capacidade de se comunicar com os outros indivíduos pelo conhecimento da leitura e de informação; aspectos da garantia de transparência, que é a liberdade de ter relações com garantia de dessegredo e clareza (a busca por segurança de informação, para evitar a corrupção fácil, transações ilícitas); e a segurança protetora, qual seja, a segurança social como

85 Em uma perspectiva coletivista ter mais liberdade aumenta o potencial das pessoas de cuidarem de si mesmas e de influenciarem o próximo, aumentando assim a capacidade do indivíduo de ser "agente" em suas escolhas. 
o auxílio fixo ao desemprego, bem como os auxílios a situações emergenciais, como crises coletivas.

Em seguida, a renda influencia as nossas liberdades, ou parte delas. O que se leva em consideração são os bens primários para o exercício de "direitos, liberdades e oportunidades, renda, riqueza e as bases sociais do respeito próprio" ${ }^{86}$, mas não somente os bens para o sustento da vida e sim, ter condições além daquilo que seja considerado decente (para os costumes de um país) que uma pessoa possua. Os bens primários são convertidos em capacidades de acordo com as características pessoais. A qualidade de vida ${ }^{87}$ se faz presente no modo como as pessoas vivem, não apenas na renda e recursos que elas gozam. O florescimento humano está interligado com a qualidade de vida e as liberdades substantivas, então, os bens são meios de se conseguir as liberdades substantivas (capacidades ${ }^{88}$ ) estruturadas na oportunidade real que o indivíduo tem para promover seus objetivos, ou seja, é visualizar as possibilidades de conversão dos bens primários na capacidade da pessoa promover seus objetivos.

Os funcionamentos são as várias coisas que uma pessoa considera valioso fazer ou ter ${ }^{89}$, daí a capacidade de uma pessoa é o pacote de combinações alternativas de funcionamentos realizáveis por ela. O conjunto capacitatório consiste nos vetores de funcionamento alternativos que as pessoas podem escolher, que refletem nas suas realizações efetivas (funcionamentos realizados). Assim, são importantes as liberdades políticas e os direitos civis básicos para o debate público na formação de valores sociais para a avaliação crítica do processo acima.

O Estado, de acordo com a Teoria da Capacidade, tem a função adicional de auxiliar os grupos com dificuldades a converter os bens primários em capacidades. A capacidade se foca nas oportunidades de satisfazer os fins por meio das liberdades substantivas, o núcleo da sua abordagem é não apenas no que a pessoa faz, mas

86 SEN, Amartya. Desenvolvimento como liberdade. São Paulo: Companhia das Letras, 2010.

87 Melhor educação e saúde ajudam a auferir rendas mais elevadas, apesar de existirem outras influências na relação entre diferenças dos padrões de vida que incluem disposições sociais comunitárias como cobertura médica (saúde), educação escolar, lei e ordem, prevalência de violência.

88 A palavra capacidade aqui está no sentido de capacidade social, ou seja, capabilidade traduzido do inglês capability.

89 SEN, Amartya. Desenvolvimento como liberdade. São Paulo: Companhia das Letras, 2010. no que ela é capaz de fazer, para realizar os objetivos da agência, como o bem-estar.

A privação de liberdade acarreta privação de capacidades, assim como pode decorrer de estados totalitários (privação de direitos civis e políticos), ausência de oportunidades substantivas de renda, saúde e educação (por exemplo, não ter como saciar a fome), ou econômicas decorrentes de negligências de serviços públicos e assistência social que impedem o aumento das liberdades pessoais. Nesse sentido, o desenvolvimento é a medida da liberdade.

Quando as receitas dos Estados se encontram em déficit orçamentário, devido a dívidas nacionais e outros fatores, não significa que a diminuição daquele seja sanado com ações extremistas de cortes de gastos, pois acarretará em possíveis futuros custos sociais. Tal situação pode ser presenciada atualmente no Brasil (na "era mensalão"), influenciada por motivos políticos, econômicos e na consequente descrença dos investidores internacionais (investimentos externos). Portanto, os comedimentos financeiros devem ser utilizados para estabilizar a macroeconomia de forma a manter os objetivos sociais.

Nesse sentido, sob a ótica aristotélica, as riquezas não são medidas pelos bens; estes são apenas um instrumento para algum outro fim. Então, as riquezas materiais propiciam um leque maior de oportunidades de escolhas, maior liberdade; porém, uma referência ao conjunto de riquezas de um Estado, o mero crescimento econômico não é um fim em si mesmo. Ele pode ajudar a conquistar o fim, através de não só elevar as rendas privadas, mas também da realização conjunta de um devido planejamento prévio para melhor oferecer os serviços sociais (por meio da administração pública) e do planejamento o financiamento da seguridade social, todos estes essenciais para o aumento das capacidades humanas.

As expectativas de vida não se elevam, necessariamente, com o crescimento do PNB (Produto Nacional Bruto) per capita. Na visão de Amartya Sen, as causas de insegurança econômica podem se dar por ausência de liberdades, como os países que lideram a "liga da fome" são a Coreia do Norte e o Sudão.

Conforme o explicado, para fins lúdicos, com base em dados gráficos ${ }^{90}$, em 1994, Estados como Kerala, na

90 SEN, Amartya. Desenvolvimento como liberdade. São Paulo: Com- 
Índia, possuíam até então uma população de 30 milhões de habitantes, com renda per capita baixa (mais baixa do que a do Brasil), porém, com excelente qualidade de vida, superando vários países emergentes, inclusive países desenvolvidos, como os EUA, em termos de taxas de sobrevivência. Portanto, não precisa haver uma "espera" de riquezas para que se intervenha em educação básica e sistemas de saúde, mediante programas adequados de serviços sociais.

O que se busca no desenvolvimento econômico é a melhora da vida que se leva, por meio da aplicação dos DESC, em que o fim primordial é a expansão das liberdades. Estas somente podem decorrer de uma contribuição conjunta de direitos, oportunidades e intitulamentos (este é "àquilo que a lei garante e apoia" ${ }^{\text {) }}$ ). Em termos ilustrativos, gráficos mostram a população negra, de países desenvolvidos (com excelentes taxas de PNB), que possui piores taxas de sobrevivência do que a população de países menos desenvolvidos como a Ín$\mathrm{dia}^{92}$. Do mesmo modo, por uma questão de prevalência da violência, os homens, em Bangladesh, possuem mais chances de viver até depois dos 40 anos do que um afro-americano no distrito do Harlem, Nova York (que, em regra, tende a ter mais condições financeiras).

É um fato que a heterogeneidade de condições influencia no bem-estar. As heterogeneidades pessoais, como as limitações físicas de doenças, idade, sexo e incapacidade podem exigir mais renda de determinada pessoa para se manter do que a média da população; diversidades ambientais, como as circunstâncias climáticas, são desafios para o Estado financeira e tecnicamente (no desenvolvimento de tecnologias); as heterogeneidades sociais, quando se trata da educação ou da prevalência da violência; as diferenças de perspectivas, quando se trata dos costumes ${ }^{93}$ das comunidades, os

panhia das Letras, 2010.

91 SEN, Amartya. Desenvolvimento como liberdade. São Paulo: Companhia das Letras, 2010.

92 SEN, Amartya. Desenvolvimento como liberdade. São Paulo: Companhia das Letras, 2010.

93 O fator social cultural na busca do desenvolvimento influencia na capacidade de agente do indivíduo em sociedade. Muitas vezes, há um conflito entre a tradição cultural e as vantagens das perspectivas tecnológicas modernas, o que não é uma relação excludente, apesar de relutâncias por parte das autoridades políticas e religiosas, entre outros. Tolher liberdades de participação em prol da defesa de "valores tradicionais" passa por cima da legitimidade das escolhas pessoais, das pessoas serem agentes em suas vidas. Essa questão, baseada no "custo-benefício" da cultura versus a modernização, deve ser decidida por meio de debates públicos democráticos, pois padrões de comportamento que influenciam nas mercadorias; a distribuição de rendas dentro da própria família, pois a renda de um membro influencia todos da família. Todas essas são heterogeneidades que influenciam as liberdades individuais e gerais.

O mecanismo de mercado, nessa discussão, é consequência de um desenvolvimento econômico, pois aquele está atrelado à troca de bens que somente é passível de ser exercida se houver a liberdade para troca, em que as rendas e mercadorias são o mínimo material para a garantia do bem-estar. A arbitrária negação de transições comerciais tem como consequência a negação de oportunidades econômicas, o que não significa que o Estado deva se abster de intervir no controle do mercado financeiro ${ }^{94}$. A eficiência dos mercados deve andar pari passo com as liberdades substantivas, para existir a equidade de liberdades substantivas. Os mercados não são livres para fazer o que podem, mas sim, o que lhes é permitido; o interesse dos comerciantes, em regra, é diverso do dos consumidores. De acordo com Smith ${ }^{95}$, não é devido à benevolência do vendedor que conseguimos determinado produto, é devido ao interesse de eles conseguirem realizar seus interesses próprios o qual pode acarretar em grandes violações ao meio ambiente ou impactos sociais negativos. É nesse viés que os governos e os direitos humanos entram para regular o equilíbrio com a atuação do mercado (criando limites).

a manutenção da "pureza da tradição nacional" pode ser uma interpretação redutiva de determinado elemento cultural. Fato é que o pensamento "tolerância ao ceticismo e heterodoxia religiosa" são características predominantemente de culturas ocidentais, são noções reducionistas por excluírem, por exemplo, as religiões budistas que respeitam o agnosticismo.

94 O aumento da importância do capital financeiro se traduz no protagonismo econômico e político dos agentes que o representam e no poder que passam a ter de impor seus interesses. Tal processo de financialização tem impacto sobre os direitos humanos, como ocorre com a situação da evasão fiscal, é a perda de contribuições tributárias que poderiam ser revertidas na expansão das operações das empresas e, portanto, na geração de novos empregos ou novas relações comerciais lucrativas. Isso cria enormes dificuldades para os Estados cumprirem com suas obrigações de direitos humanos. Todos os direitos, sejam civis, políticos, sociais, econômicos ou culturais, geram custos. Esses custos exigem fontes de financiamento que os cubram, os recursos vêm da cobrança de impostos. Se a cobrança de impostos é fraca, as possibilidades dos Estados são automaticamente reduzidas. CASTRO, Jose Miguel Camacho. El papel de las instituciones de control financiero sobre los derechos humanos en el contexto latino-americano. Revista de Direito Internacional, Brasília, v. 13, n. 1, p. 156-168, 2016.

95 SEN, Amartya. Desenvolvimento como liberdade. São Paulo: Companhia das Letras, 2010. 
As distribuições de bens são produtos de várias relações, desde políticas regionais, internacionais por meio de leis, tratados, negociações, guerras, todos sujeitos a críticas possibilitadas pelo diálogo mundial. No momento em que se oferta a democracia e a liberdade política, tem-se, ao mesmo tempo, a chance de aumentar as capacidades dos cidadãos, pois com ela há a oportunidade destes se queixarem das carências econômicas. Nesse ponto, surge a importância da liberdade de expressão, comunicação, discussão para delimitar quais são as necessidades econômicas e, consequentemente, pressionar/incentivar as autoridades a escutá-los.

A democracia leva em consideração não apenas as vozes das instituições formais, mas também, primordialmente, as vozes de diversas partes da população. As instituições têm, por um lado, a função de melhorar a justiça, quando analisadas no seu papel social e no comportamento individual, assim como podem ser plataformas relevantes para construir um raciocínio crítico acerca dos valores, aumentando as capacidades para o debate público.

Nesse sentido, há vários movimentos organizados que servem para preencher lacunas na sociedade e que saem do debate na mídia. Essa liberdade promove amplo debate em prol de uma política mais justa, o que exige ativismo por parte dos cidadãos para se engajarem.

Os Direitos Humanos são o raciocínio ético de fundamentação jurídica das políticas comuns a todos, dirigidos a todos os indivíduos que possam ajudar a garanti-los. A liberdade pessoal é digna de ser garantida a quem importa, e, devido à igualdade de liberdade, todos importam.

O essencial para o pluralismo é o elo entre as oportunidades econômicas, a cultura e os direitos, perpassando a liberdade de comunicação, assim como o incremento da educação, para o indivíduo conseguir sua qualificação profissional. Os costumes e valores influenciam nas liberdades: o exercício da liberdade é mediado por valores que, por sua vez, são influenciados por discussões públicas, interações sociais, as quais, por sua vez, são influenciadas pela liberdade de participação.

Por essa ótica, as pessoas têm a responsabilidade de se desenvolver e influenciar na vida do todo. Afinal, os seres humanos são reflexivos e interagem com os outros. Assim, fazem-se necessárias as liberdades substantivas para existir a atribuição de responsabilidades, que são extremamente dependentes de condições sociais, pessoais e ambientais ${ }^{96}$. Daí a importância da inclusão de direitos de segunda geração nos tratados internacionais de direitos humanos que permitem indicar as questões subjacentes a ideias gerais de desenvolvimento global e democracia deliberativa, ligadas à importância de aprimorar as capacidades humanas ${ }^{97}$. O papel do desenvolvimento econômico é aumentar as oportunidades de levar uma vida livre, complementarmente com o desenvolvimento social, possibilitando, assim, o aumento das capacidades e das responsabilidades.

\section{DAS LIBERDADES E DOS DIREITOS SOCIAIS AO MÍNIMO EXISTENCIAL}

Convém ressaltar a classificação doutrinária dos direitos em gerações históricas da formação dos estados e de seus ordenamentos jurídicos. Na Idade moderna, segundo Bonavides, com o absolutismo monárquico, o Estado passou a ser visto como inimigo da liberdade, daí surgem os Estados de Direitos ocidentais (Estados Mínimos), que com o formalismo sintetiza as liberdades individuais (direitos de personalidade) e procura acabar com despotismo. No século XVIII, em meio à Revolução Francesa, tem-se a primeira fase do constitucionalismo burguês, a qual incitou o povo para a consciência das liberdades políticas (princípio liberal), da liberdade do homem perante o Estado, e da participação total e indiscriminada deste na formação do Estado (princípio democrático), chegando ao sufrágio universal, assim se tinha a defesa do Princípio da Representação e, até mesmo, a defesa da divisão tripartida de poderes para a limitação da soberania estatal. Daí surgem a classificação dos direitos civis e políticos assegurados em documentos constitucionais americanos e franceses, cuja prioridade era a intervenção mínima do Estado na liberdade do indivíduo - eram direitos de resistência ao ente estatal (liberdade meramente negativa), fundamentados nas teorias de Locke, Montesquieu e Smith.

Acontece que, ao se apoderar do poder político, essa classe já não tinha interesse em manter a universalidade de seus princípios. Além disso, o que faltou levar em consideração eram as consequências referentes à liber-

96 SEN, Amartya. Ideia de justiça. São Paulo: Companhia das Letras, 2011.

97 SEN, Amartya. Ideia de justiça. São Paulo: Companhia das Letras, 2011. 
dade ética, o conceito de liberdades do liberalismo não calculou o fator econômico e social com a liberdade humana, considerou como se todos fossem dotados de iguais capacidades.

Desse modo, no séc. XX, as classes operárias mostraram resistência, inclusive teórica, às mazelas do capitalismo, por exemplo a corrente marxista mostrou a densidade das deformações do sistema capitalista (a ausência estatal foi sintomática na Revolução Industrial com a concentração de capitais, monopólios, trustes, abusos de liberdade econômica, contratual provocando crises e exigências agressivas dos operários); já Rousseau defendia a criação de um Estado Social dentro do constitucionalismo democrático com a universalização do sufrágio, onde se buscava a mediação da igualdade política com a desigualdade social. O Estado Social é de cunho intervencionista, requer a presença militante do poder político nas esferas sociais, pela impossibilidade em que o indivíduo tem de prover necessidades existenciais mínimas devido à fatores alheios à sua vontade.

Consequentemente, surge a segunda geração de direitos referente à igualdade lato sensu, introduzidos no Estado Social (exigindo ações positivas/intervencionistas pelo ente público ${ }^{98}$ ), como os direitos econômicos, sociais e culturais, e também os coletivos, os quais tinham cunho programáticos.

Por fim, o Estado pós-Social, os direitos de terceira geração são decorrentes do Princípio da Fraternidade, com titularidade transindividual ${ }^{99}$, como o direito ao desenvolvimento, à paz, ao meio ambiente, à comunicação e ao patrimônio comum da humanidade; e os de quarta geração, ainda em concretização decorrente da globalização dos direitos fundamentais, são o direito à democracia, à informação, o direito do pluralismo, numa dimensão de máxima universalidade para todos os planos de convivência.

Nesse ínterim, visualiza-se que os direitos do Estado Social estão estritamente relacionados com o segundo aspecto da ausência de liberdades de Amartya Sen, quando afirma que a ausência de liberdades pessoais (e, posteriormente, coletivas) ocorrem pela ausência de oportunidades substantivas ou econômicas decorrentes do descaso estatal à assistência social e serviços, confor-

98 BONAVIDES, Paulo. Do Estado liberal ao Estado social. São Paulo: Malheiros, 2007.

99 BONAVIDES, Paulo. Curso de direito constitucional. 11. ed. São Paulo: Malheiros, 2001. me o explicado no capítulo anterior.

Assim, com a não prestação estatal positiva, há a limitação de capacidades para o indivíduo, e a consequente redução de oportunidades reais da pessoa conseguir a qualidade de vida para exercer os projetos que almeja, ou seja, o desenvolvimento econômico estagna e haverá um ciclo vicioso de carências de bens materiais básicos que constituem o mínimo existencial. No Estado Pós-Social, as prestações estatais positivas auxiliam a garantir o acesso aos direitos sociais, além de oportunizar melhores condições de realização dos próprios direitos clássicos de liberdade (civis e políticos), já que sem os bens materiais mínimos não há a possibilidade da pessoa participar da vida política ou desenvolver plenamente a sua personalidade - eles são instrumentos para atingir a finalidade que é o bem-estar e a qualidade de vida. As dimensões da liberdade, de Sen, pressupõe a presença do Estado para se concretizarem de maneira a tornar o indivíduo autônomo, e também, para o alcance do desenvolvimento econômico e social em termos plurais.

Em consonância às prestações positivas do Estado para a garantia dos direitos sociais, e direitos civis e políticos, Novais interpreta que as duas "espécies" de direitos dependem de vários tipos de obrigações (positiva direita e indireta ou negativa) estatais. Ao alegar que o judiciário sempre restringe a concessão de direitos sociais (como já visto no segundo capítulo), o autor defende, como Sen, que o Estado precisa da atuação positiva tanto judiciária quanto administrativa para que se garantam tais direitos e se aumentem as possibilidades de exercer os direitos fundamentais de liberdade (civis e políticos).

O mínimo existencial prescinde da atuação positiva e negativa do poder público para com os direitos civis e políticos quando precisa alocar recursos para a segurança pública ou quando oferta a liberdade de crença eximindo as instituições religiosas da coleta de impostos. Assim como tal mínimo prescinde da atuação positiva e negativa do poder público para com os direitos sociais, concedendo educação em escolas públicas ou quando se compromete (como, por exemplo, em tratados internacionais) a não legislar diminuindo o alcance de direitos trabalhistas já positivados (não retrocesso). Além disso, as atuações públicas em qualquer desses grupos influenciam o outro, visto que são indivisíveis, são todos direitos fundamentais. Então, a limitação de direi- 
tos sociais impede o exercício dos direitos de liberdades clássicos. Para Novais, as concessões de direitos sociais em decisões judiciais são influenciadas pelas escolhas políticas de dotação orçamentária.

$\mathrm{Na}$ ótica de Sen, as escolhas políticas afetam as alocações de recursos, desde o momento da escolha dos princípios da justiça sob o véu da imparcialidade para a diminuição de injustiças na sociedade, quanto no momento em que se constata a necessidade do aumento de liberdades para o aumento de capacidades. Daí os Estados, as instituições, a sociedade civil — e o homem - como agentes têm a responsabilidade de construir oportunidades reais individuais e coletivas, por meio dos DESC para o aumento de capacidades.

Novais também ressalta a distinção entre reconhecer direitos e garanti-los juridicamente ao se criar condições fáticas ao cidadão que permita o acesso ao bem protegido. $\mathrm{Na}$ visão de Sen, cada sociedade tem suas exigências práticas, assim como cada indivíduo tem suas necessidades diferenciadas para alcançar seus objetivos. As capacidades reais dependem das disposições sociais; dentre elas, está a função assistencial pública para a garantia das liberdades e do desenvolvimento coletivo.

Destarte, a liberdade, para Sen, está vinculada não apenas a não intervenção e não coação, mas com oportunidades, cuja base está nos direitos econômicos, sociais, e culturais para os indivíduos terem melhores condições de realizarem seus direitos de liberdade. Assim, Novais e Sen defendem que o mínimo existencial deve ser ampliado para a existência digna do ser humano, noção essa fundamentada na dignidade da pessoa humana e no direito à vida ${ }^{100}$ num contexto sociocultural de condições reais, associadas a prestações materiais, considerando o desenvolvimento e disponibilidade do Estado com a evolução cultural e as necessidades individuais (relativas à personalidade, participação e integração comunitária).

\section{Considerações finais}

Como se pode observar ao longo deste artigo, o histórico dos tratados internacionais demonstra a con-

100 NOVAIS, Jorge Reis. Direitos sociais: teoria jurídica dos direitos sociais enquanto direitos fundamentais. Coimbra: Editora Wolters Kluwer Portugal, 2010. p. 195. seguinte visão da indivisibilidade dos DESC pela Conferência de Teerã, seguida da criação dos mecanismos de controle de tais direitos, os quais determinam aos Estados partes a submissão anual às Comissões de relatórios, com o objetivo de torná-los eficazes.

Por conseguinte, por meio da concepção de Novais, refutam-se as críticas que desconsideram os direitos sociais como direitos fundamentais, cuja superação se dá pela comparação com a aplicabilidade destes com os direitos civis. Assim, faz-se uma delimitação do que é o mínimo existencial, conceito interpretado da forma mais ambiciosa possível, além de se discutir sua implicação nos ordenamentos jurídicos, a fim de promover a dignidade da pessoa humana por meio da plena fruição dos direitos fundamentais e o pleno desenvolvimento da personalidade.

Em seguida, fica demonstrado o papel do desenvolvimento para complementar a discussão da aplicabilidade dos DESC, pela posição de Amartya Sen, onde desenvolvimento é a medida das liberdades. Em a "Teoria da Capacidade", resta comprovada que a expansão das capacidades das pessoas em levar o tipo de vida que valorizam está relacionada com a quantidade de liberdade que elas possuem, o que depende de vários fatores, inclusive de políticas públicas. Então, o mecanismo de mercado é analisado como consequência de um desenvolvimento econômico, o qual deve se dar juntamente com as liberdades substantivas.

Assim, o objetivo do desenvolvimento econômico é melhorar a vida humana, por meio dos DESC, possibilitando o acesso a bens primários para o exercício de direitos, liberdades e oportunidades, renda, riqueza e as bases sociais do respeito próprio. O último diz respeito ao mínimo progressivo que propicia condições de realizarem as capacidades e as transformarem em funcionamentos e, assim, constituir suas identidades.

A Teoria de Sen é especial para a compreensão das distribuições de bens na sociedade, a partir da construção da posição original, em que o homem, sob o véu da ignorância do contrato social hipotético, escolherá seus princípios básicos ausente de parcialidades, com o fim de evitar os benefícios de classes e objetivos pessoais. A ética, sob a perspectiva de Nyaya, e Niti, justifica o intuito do presente trabalho em fundamentar a relação do desenvolvimento econômico e social com a qualidade de vida e o Direito, por meio das transformações das liberdades em capacidades e em realizações, as quais 
necessitam do fator felicidade. Tal fator está ligado à identidade, à escolha de combinações de funcionamentos que as pessoas querem seguir em suas vidas, onde o Estado surge como um facilitador, ou seja, aquele que concede oportunidades de acesso a tais escolhas por meio do diálogo com as mais variadas vozes sociais.

Devido ao discutido, tem-se a importância do cumprimento dos DESC pelos Estados membros na garantia da efetivação dos direitos fundamentais para a promoção do aumento de capacidades humanas, em prol da fruição do bem-estar e dos objetivos individuais e sociais. Desse modo, o PNDH-3, no Brasil, surge para consolidar a promoção de tais direitos os quais são constantemente esquecidos em momentos de crises econômicas e políticas. Nesse ínterim, os movimentos sociais, comunidades indígenas, organizações de direitos humanos e de direito das mulheres, dentre outros grupos, são os agentes mais dispostos a utilizar dos tribunais como instrumentos de mudanças sociais. Mediante a diversidade, resta configurada a universalidade e indivisibilidade dos direitos humanos em respeito à dignidade da pessoa humana.

Por fim, com a garantia das capacidades, há o aumento de liberdades substantivas e aumento das possibilidades da fruição do bem-estar humano e da qualidade de vida; consequentemente, há o desenvolvimento social, através do diálogo público.

Assim, o presente artigo responde à problemática proposta pela utilização da interpretação ampla do mínimo existencial na fundamentação de medidas judiciais que concedam direitos sociais no Brasil, com a finalidade de desmistificar as automáticas negativas de reais ponderações de princípios nos casos práticos do judiciário.

\section{REFERÊNCIAS}

ALEXY, Robert. Teoria e direito público: teoria dos direitos fundamentais. Tradução de Virgílio Afonso da Silva. 2. ed. São Paulo: Malheiros Editores, 2017.

ANDRADE, Diogo de Calasans Melo. Políticas públicas, mínimo existencial e Poder Judiciário: a questão do direito à moradia. Revista Brasileira de Politicas Públicas, Brasília, v. 6, n. 1, p. 150-165, 2016. Disponível em: https://www.publicacoesacademicas.uniceub.br/ RBPP/article/view/3805. Acesso em: 22 out. 2018.
BAPTISTA, Eduardo Correia. Ius Cogens em direito internacional. Lisboa: Lex, 1997.

BONAVIDES, Paulo. Curso de direito constitucional. 11. ed. São Paulo: Malheiros, 2001.

BONAVIDES, Paulo. Do Estado liberal ao Estado social. 8. ed. São Paulo: Malheiros, 2007.

BRASIL. [Constituição (1988)]. Constituição da República Federativa do Brasil. Disponível em: http:/ /www.planalto. gov.br/ccivil_03/constituicao/constituicao.htm. Acesso em: 8 jan. 2018.

BRASIL. Decreto no 591, de 6 de julho de 1992. Pacto de Direitos Econômicos, Sociais e Culturais, 1966. Disponível em: http://www.planalto.gov.br/ccivil_03/decreto/1990-1994/d0591.htm. Acesso em: 3 nov. 2017.

BRASIL. Decreto ñ 592, de 6 de julho de 1992. Pacto Internacional Sobre Direitos Civis e Políticos, 1966. Disponível em: http:/ /www.planalto.gov.br/ccivil_03/decreto/1990-1994/d0592.htm. Acesso em: 7 jan. 2018.

BRASIL. Decreto no 7.030 de 14 de dezembro de 2009. Convenção de Viena sobre o Direito dos Tratados de 1969. Disponível em: http://www.planalto.gov.br/ ccivil_03/_ato2007-2010/2009/decreto/d7030.htm. Acesso em: 7 jan. 2018.

BRASIL. Relatório da Sociedade Civil Sobre o Cumprimento, pelo Brasil, do Pacto Internacional de Direitos Econômicos, Sociais e Culturais. Brasilia, 2000. Disponível em: http:// www.camara.leg.br/Internet/comissao/index/perm/ cdh/Pidesc\%20-\%20Relat $\%$ C3\%B3rio\%20Final.html. Acesso em: 19 jun. 2017.

CASTRO, Jose Miguel Camacho. El papel de las instituciones de control financiero sobre los derechos humanos en el contexto latino-americano. Revista de Direito Internacional, Brasília, v. 13, n. 1, p. 156-168, 2016. Disponível em: https://www.publicacoesacademicas.uniceub.br/ rdi/article/view/3967. Acesso em: 22 out. 2018.

ECOSOC. Princípio de Limburgo para Implementação do Pacto Internacional de Direitos Econômicos, Sociais e Culturais. 1986. Disponível em: https://www.escr-net.org/ resources/limburg-principles-implementation-international-covenant-economic-social-and-cultural. Acesso em: 8 jan. 2018.

GALDINO, Flávio. Introdução à teoria dos custos dos direitos: direitos não nascem em arvores. Rio de Janeiro: Lumen Juris, 2005. Disponível em: https:// bdjur.stj.jus.br/jspui/bitstream/2011/2180/ 
Introdu $\% \mathrm{C} 3 \% \mathrm{~A} 7 \% \mathrm{C} 3 \% \mathrm{~A} 3 \mathrm{O} \_\% \mathrm{C} 3 \% \mathrm{~A} 0 \_$Teor ia_dos_ Custos.pdf. Acesso em: 8 set. 2018.

LANGFORT, Malcolm. Judicialização dos direitos econômicos, sociais e culturais no âmbito nacional: uma análise sócio jurídica. Revista Internacional de Direitos Humanos, São Paulo, v. 6, n. 11, p. 98-133, 2009.

LIMA, Jayme Benvenuto Jr. Acesso aos sistemas global e regional de proteção dos direitos humanos: manual de direitos humanos internacionais. São Paulo: Loyola, 2002. Disponível em: https://www.uniceub.br/media/181730/ Texto4.pdf. Acesso em: 22 out. 2018.

LEÃO, Renato Zerbini Ribeiro. O acesso direto dos indivíduos ao Comitê de Direitos Econômicos, Sociais e Culturais da ONU. Universitas Relações Internacionais, Brasília, v. 11, n. 1, p. 29-38, jan./jun. 2013. Disponível em: www.google.com.br/search?q $=\mathrm{O}+$ Acesso + direto + dos + indivíduos $+\mathrm{ao}+$ Comitê $+\mathrm{de}+$ Direitos + Econô micos $\% 2 \mathrm{C}+$ Sociais $+\mathrm{e}+\mathrm{Culturais}+\mathrm{da}+\mathrm{ONU} \&$. Acesso em: 22 out. 2018.

MACHADO, Jónatas E. M. Direito internacional: do paradigma clássico ao pós-11 de setembro. 4. ed. Coimbra: Coimbra Editora, 2013.

MARTY, Mireille Delmas. Por um direito comum. São Paulo: Martins Fontes, 2004.

MAZZUOLI, Valério de Oliveira. Teoria geral do controle de convencionalidade no direito brasileiro. Revista de Informação Legislativa, Brasilia, ano 46, n. 181, p. 113 139, jan./mar. 2009.

NOVAIS, Jorge Reis. Direitos sociais: teoria jurídica dos direitos sociais enquanto direitos fundamentais. Coimbra: Editora Wolters Kluwer Portugal, 2010.

OEA/CIDH. Informe Anual de la Comissión Interamericana de Derechos Humanos: 1985-1986. Disponível em: https://www.cidh.oas.org/annualrep/85.86span/Cap5. htm\#I.dificultades encontradas por los organismos de derechos humanos. Acesso em: 8 jan. 2018.

OEA. Convenção Americana sobre Direitos Humanos: Pacto de San José da Costa Rica, 1969. CIDH. Disponível em: https://www.cidh.oas.org/basicos/portugues/c.convencao_americana.htm. Acesso em: 8 jan. 2018.

ONU. Committee of Human Rights. General comment $n^{0} .17$ : Article 24 (Rights of the child). Thirty Fifth session, 1989. HRI/GEN/ 1, Rev.9, v. I, 27 May 2008, p. 276. Disponível em: www.ohchr.org/Documents/ HRBodies/TB/HRI-GEN-1-REV-9-VOL-I_en.doc.
Acesso em: 7 jan. 2018.

ONU. Committee on Economic, Social and Cultural Rights. General comment $n^{o}$.3: The nature of States parties' obligations (art. 2, para. 1, of the Covenant). Report on the Fifth Session, 1990. HRI/GEN/1/Rev.9, v. I, 27 May 2008, p. 276. Disponível em: www.ohchr. org/Documents/HRBodies/TB/HRI-GEN-1-REV9-VOL-I_en.doc. Acesso em: 7 jan. 2018.

ONU. Declaração e Programa de Ação de Viena: Conferência Mundial sobre Direitos Humanos, Viena, 1993. CEDIN, p. 22. Disponível em: https://www.oas.org/dil/ port/1993/Declaracao/de/1993.pdf. Acesso em: 8 jan. 2018.

ONU. Pacto Internacional de Direitos Civis e Politicos. Resolução n. ${ }^{\circ}$ 2200-A (XXI). Nova York, 1966.

PIOVESAN, Flávia. Direitos humanos e direito constitucional internacional. 12. ed. São Paulo: Saraiva, 2011.

SARLET, Ingo Wolfgang. Prestação jurisdicional, dignidade (da pessoa) humana, mínimo existencial e justiça constitucional: algumas aproximações e alguns desafios. Revista CEJUR / TJSC, v. 1, n. 1, p. 29-44, 2013.

SEN, Amartya. Desenvolvimento como liberdade. São Paulo: Companhia das Letras, 2010.

SEN, Amartya. Ideia de justiça. São Paulo: Companhia das Letras, 2011.

SEN, Amartya. Identidade e violência: a ilusão do destino. São Paulo: Iluminuras, 2015.

TAQUARY, Eneida Orbage. A proteção à pessoa humana: sistema normativo de proteção global geral. Universitas Jus, Brasília, v. 25, n. 1, p. 143-151, abr. 2014. Disponível em: https://www.publicacoesacademicas. uniceub.br/jus/article/viewFile/2387/2292. Acesso em: 22 out. 2018.

TEREZO, Cristina Figueiredo. A atuação do sistema interamericano de proteção dos direitos humanos na defesa dos direitos econômicos, sociais e culturais. 2011. Tese (Doutorado em Direito) - Universidade Federal do Pará, Belém, 2011.

TRINDADE, Antônio Augusto Cançado. Tratado de direito internacional dos direitos humanos. 2. ed. Porto Alegre: Sergio Antonio Fabris, 2003. v. 1.

TRINDADE, Antonio Augusto Cançado. Direito das organizações internacionais. Belo Horizonte: Del Rey, 2002. 
Para publicar na Revista de Direito Internacional, acesse o endereço eletrônico www.rdi.uniceub.br ou www.brazilianjournal.org.

Observe as normas de publicação, para facilitar e agilizar o trabalho de edição. 